\title{
血管鋳型法による実験的急性胃潰瘍の胃粘膜 微細血管構築に関する走查電子顕微鏡的研究
}

\author{
岡山大学医学部第 1 外科教室（主任：折田薫三教授）
}

近沢信 儀

(昭和 54 年 7 月 30 日受稿)

Key words : ストレス蛽暍, メルコックス樹脂, 毛細血管の蛇行, 血行の途絶, 樹脂の流出像.

\section{緒喜}

近年, 急性胃病変への関心が高まっているが, 発 症が急激で急性に経過し治癒するため，その病態把 握は容易ではない，中でも最近とくにストレス 潰瑝が注目されているが、ストレス潰㾥の急性 の胃粘膜変化は，並木 ${ }^{11}$, 川井 ${ }^{2}$, 長与 ${ }^{3)}$ 等が報 告しているごとく，出血性ビランの多発ある いはビマン性の粘膜出血であり，その変化は主とし て表在性にとどまる。一方ラットに種々の方法でス トレスを加えると周知のごとく腺胃体部に出血性ビ ランが出現し，この潰瘍性変化はヒトのそれと多く の類似点を有している。ストレス潰湟発生の因子は 多元的であり，酸・ペプシンの分泌元進などの攻撃 因子と粘膜血流，粘液産生，胃粘膜関門などの胃粘 膜の防糗因子とが複雑に関与しているものと推定さ れている，本研究では，その中でも防禦因子の一つ である胃粘膜の血流上の変化を胃粘膜内の微細血管 構築の変化を観察することにより解析し，ストレス 潰䀛発生の要因と血流の関係を解明せんと試みた。

消化管の微細血管構築とくに胃湍瘍と循環障害に 関する研究は，Virchow')をはじめ Bergman ${ }^{5)}$, Barclay $^{6)}$, Barlow ${ }^{7}$ 等外〈の学者により古〈から研究さ れてきたが，いまだ十分に解明されたとはいえない。 一方ストレス潰場の研究は Rokitansky ${ }^{8)}$ の神経障害

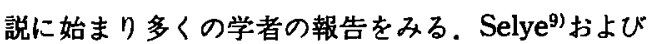
その門下生によりストレスと消化性潰寡との関係が 展関された。なお実験的ストレス測瘍の負荷方法に は種々あるが, Rossi10), Bonfils ${ }^{11)}$ 等は拘束による 負荷方法を用いた。 Takagi ${ }^{12)}$ と岡部13) とはストレ ス負荷方法に改良を加えて，ほほ一定のストレス潰 榢の $100 \%$ 発生を報告し, 水漫拘束ストレス負荷方法
を確立した．本研究では，この水浸拘束による方法 をストレス負荷に用いた。

一方微細循環の観察方法は, 連続切片法, 血管染色法, 血管内色素注入法, 血管造影法等がおこなわれてきたが, これらはいずれも二次元的観察でありかつ光学顕微 鏡によるため, 三次元的な微細血管構築の詳細は不 明な点が多い，最近に至り，合成樹脂鋳型法が開発 され，重合メチルメタクリレート注入法による血管 鋳型法を用いて Murakami14) は実䣖動物の各種正常 臓器の微細血管棈築を走查電子顕微鏡 (以下 SEM) の応用により詳細に報告した。

著者は急性胃䟺瘍成因追究の目的で，水浸拘束ス トレス負荷方法により奉験的ストレス漬瘍を作成し， メルコックス樹脂注入法により胃粘膜の微細血管鋳 型を作製して，ストレス潰㾇発生時における胃粘膜 の血行障害の経時的変化を SEM で実験観察をおこ なった。一方ストレス刺激は迷走神経を介して胃潰 㿋形成に関与し，两側幹迷走神経切断 (以下幹迷切) によりストレス潰饾の発生はほぼ抑制されることは よく知られている．著者は幹迷切後ストレスを負荷 し，その胃粘膜微細血管構築におよぼす予防的影響 をまたストレス負荷後の自然治癒傾向を同様に血 管鋳型を作製して SEM で実験観察をおこない2 3の知見を得たので報告する。

\section{実赜材料と実験方法}

1) ストレス負荷方法

実験動物として体重 $200 \mathrm{~g}$ 前後のウイスター系雄 ラットを使用した，ストレス潰瘍の作成は Takagi ${ }^{12)}$ ， 岡部(3)に準じ，金網の飼育箱に入れ，水のみ自由に 与之，24時間絶食の後，拘束ゲージに固定し，21〜 $23^{\circ} \mathrm{C}$ の水槽に胸骨中部まで浸すいわゆる水浸拘束ス 
トレス負荷方法を用いた，ストレス負荷は30分，1 時間, 2 時間， 3 時間， 6 時間，12時間，18時間, 24時間の 8 群に分け経時的に屠殺して標本を作成し， それぞれ観察を行なった。

\section{2 ) 两側幹迷走神経切断術}

手術侵襲が除去されると思われるストレス負荷 1 週間前に, ラットをネンブタール麻酔下に開腹し， 腹部神経幹の噴門部より $5 \sim 10 \mathrm{~mm}$ 中枢側の高さで前 枝・後枝とも幹迷切を施行した。

3）ストレス負荷後の自然治痖傾向

水浸拘束ストレス負荷 2 時間後およU゙24時間後, ただちにストレスを解除し，金網の飼育箱に入れ， 水と食触を自由に与之，ストレス解除後の自然治癒 傾向を観察した。

4）血管鋳型標本の作製および観察方法

実験に用いたラットをエーテル麻酔下で開腹, 開 胸し, 胸部大動脈よりポリエチレンチューブを挿入, 右心耳を切開したのち，ポリエチレンチューブより へパリン加生理食塩水にて灌流後, メルコックス樹 脂（大日本インキ林製）を注入硬化させた。樹脂注

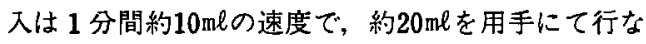
い, 肉眼下に胃壁内に樹脂が流入, 充满し, 右心耳 よりの樹脂流出を確認したのち，樹脂注入を中止し， 胸部大動脈および右心耳を閉鎖して樹脂の硬化を待 った。この注入された樹脂は $5 \sim 8$ 分間で硬化し, 耐アルカリ性の硬化物を形成した。樹脂硬化後, 胃 を摘出し大赖側に沿って切り開き, 実体顕微鏡で胃 粘膜の浩瑒形成の程度を確認した後，20\%苛性カリ 溶液中に約 6 日間浸し，組織を十分腐触溶解した。 次いで弱い流水中に浸し水洗して溶解組織を除去し， さらに超音波洗浄を約10２0秒間行ない十分な組織 の除去を行なった。この血管鋳型標本は上昇系列ア

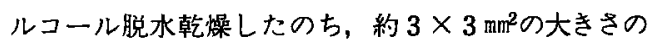
ブロックに切断し，接着凨で試料台に固定した，次 いで Eiko-Ion-coata-IB3 中で金を蒸着 L, JSM-P15 型走查電子顕微鏡で三次元的に観察した。

5) 組織標本の作製およU゙観察方法

実験に用いたラットをエーテル森酔下にて開腹, 胃を摘出し大椥側に沿って切開し，生理食塩水にて 軽く洗浄し，実体顕微鏡で胃粘膜の瀆場形成の大き さを計測したのち，適当な大きさのフロックに切り 出し, $2.5 \%$ グルタールアルデヒドで 2 時間固定, 0.2 Mカコジレート酸緩衝液で12２4時間洗净後，2\% オスミウム酸緩衝液で 2 時間固定, 上昇系列アルコ 一ル脱水乾燥したのちエポン 812 に包埋した。次い
で準超薄切片を作成し、トルイシンブルー染色を行 なったのち, 光学顕微鏡で観察した.

\section{钼 察 結 果}

\section{1 ) ラット正常胃の微細血管構築}

著者がここでいう正常胃とは，金網の咱育箱に入 れ，24時間水のみ自由に与えて絶食を行い，エーテ ル麻醉下で血管鋳型を作製したラット胃のことで， 他の実験群に対し对照として観察したものである. ラットの胃は前胃部と腺胃部（胃体部，前庭部）と に区別されるが、ラットのストレス潰演は腺胃部と くに腺胃体部に出現するため, 腺胃体部の正常微細 血管構築について記载することとする。

腺胃体部の血管鋳型の断面をSEM の弱拡大で観 察（図 1 ）すると，図中 S は漿膜血管網，Mは粘膜 下血管網，Cは上行する粘膜細動脈で，この細動脈 はお互に梯子状の吻合枝を持っている、Vは集合細 静脈を示す．次に粘膜最表層の血管粠筑（图2）を 見ると，上行してきた粘膜細動脈が胃小简をとりま いて類円形の規則正しい毛細血管網を形成し，やや 太さを增した集合細静脈へ流入し，この集合細静脈 は分枝を持たず直線的に下行して粘膜筋板を貫通し 粘膜下首でほほ直角に集合静脈へとつづく，以上の ごとく腺胃体部の血管はよく発達し, 粘膜下血管網, 粘膜固有層の上行細動脈相互の連絡網，粘膜表層の 毛細血管網を有し，横の連絡網もよく発達している. 2 ) 実駼的ストレス潰瘍

急性胃潰瘍の発生要因と胃粘膜の血行障害との関 係を明らかにする目的で，実駼的急性胃清佰として 水浸拘束ストレス負荷によるストレス瀆瘍を経時的 に作成して胃粘腊微細血管構築の変化を観察した。 ストレス負荷 30 分， 1，2，3，6，12，18，24時間後 の 8 群に分け経時的変化とくに毛細血管, 集合細静 脈, 細動脈の変化について観察を行った。

ストレス負荷 30 分後の胃粘膜を実体顕微鏡で観察 すると, 出血, ビランなどの胃粘膜の変化は全く認 められず, 对照群の胃粘膜と変りは認められない。 組織標本の検索では, 粘膜下血管の動脈壁の平滑筋

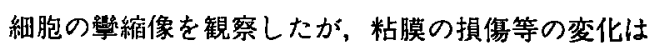
全く認められなかった。

胃粘膜血管鋳型の観察（図 3，4）では，㹟小化 した毛細血管の高度な蛇行を認めた部があり、また 毛細血管が先細りし, 血行の途絶像も部分的に観察 きれた。なおこのような血管変化は集合細静脈遠位 部において，その程度が著しかった。すなわち毛細 
血管の蛇行と狭小化に伴なう毛細血管網の陥凹を示 す部が多く観察されたが，他方では集合細静脈およ び流入毛細血管の拡張像を示寸部があり，この流入 毛細血管にも蛇行像が観察された。しかしストレス 負荷30分後では毛細血管網の網状構造の脱落は認め られず,その構造はほば保たれていることが多い(困 3）。なおこの血管鋳型標本を強拡大で観察すると, 毛細血管の先細り状の途絶像および蛇行像がより明 瞭に観察された（図4）.

以上を要約するとストレス負荷 30 分後の血管鋳型 では，毛細血管の等縮によるその部の蛇行像が見ら れ，また狭小化した部の陷凹および先細り状の途絶 像が観察された。

ストレス負荷 1 時間後の胃粘膜の実体顕微鏡によ る観察では，胃粘膜に極く軽度の出血巣が部分的， 散在性に見られたが，ビランは認められなかった。 組織標本の検索では，2４個の腺細胞の極く小範 囲で最表層の粘膜損傷が観察されたにすぎなかった。 また粘膜下層の動脈壁の平滑筋細胞の繁縮像を観察 した。

血管鋳型の観察（図 5 ）では，毛細血管および毛 細血管網の蛇行はストレス負荷30分後の条件下のも のと比較するとむしろ軽減する傾向が見られたが， なお引き続き観察された。しかし毛細血管の狭小化 は增強し，先細りによる血行の途絶像は増加する。 また毛細血管網の陥凹も多く見られ，血管網の血行 の途絶による部分的脱落が観察されるようになる。 一方流入毛細血管の蛇行は軽くなっていたが, 拡張 像は集合細静脈と共に観察された。細動脈には狭小 化あるいは拡張像などの変化は観察されなかった。 また所々に血管の破綻に一致する類球状の樹脂の流 出像が散在性に観察された。

以上のようにストレス負荷 1 時間後では，負荷 30 分後の条件下に引き続き蛇行像が見られ，虚血性変 化は増強していた。

ストレス負荷 2 時間後の胃粘膜の実体顕微鏡での 観察では，胃体部粘膜の出血と浅い点状あるいは短 い線状の粘膜ビランを散在性に認めた，組織標本の 検索では，粘膜固有層中層に達する粘膜の脱落と細 胞の変性および胃内腔へ向う粘液の流出を観察し， 一方粘膜下層の動脈壁の平滑筋細胞の謷縮像を負荷 1 時間後のものと同程度に観察した。

血管鋳型の観察（図 6，7）では，毛細血管と毛 細血管網および細動脈の蛇行は軽度で, 負荷 1 時間 後のものに比へると蛇行の程度は減少している。一
方毛細血管の狭小化と先細り状の途絶は增強し, 毛 細血管網の脱落も増強して広範囲に脱落が見られる。 なお同部の細動脈は途絶し，近位の集合細静脈およ び流入毛細血管には搪張像が見られるが軽度となっ ている（図6）.しかし同条件下の同一群のラットの 胃の血管鋳型の中には，大小不同の小球状の樹脂の 流出を伴なう毛細血管の途絶と，それに伴なう限局 した毛細血管網の脱落した像が打ち抜き像のごとく 観察されるものもあった，その近位の毛細血管には や、狭小化が見られ，集合細静脈と流入毛細血管に は拡張像が観察されたがこのようなラットでは， この拡張像はこれまでの条件下のものと比較し高度 に認められた（図７）。

以上のようにストレス負荷 2 時間後の条件下では, 虚血性変化が優先している血管鋳型とうっ血性変化 が優先している血管鋳型の両方が観察された.

ストレス負荷 3 時間後の胃粘膜の実体顕微鏡での 観察では，点状あるいは線状の粘膜ビランが観察さ れここれらより相当量の出血を認めた。組織標本の検 索では，ストレス負荷 2 時間後の条件下のものと同 じ程度の深さで,や、範囲の広い粘膜損傷と細胞の 破壇および粘夜の流出を観察した。また粘膜下動脈 壁の平滑筋細胞の繁縮像を観察した。

血管鋳型の観察（図 8 ）では，広範囲の毛細血管 網の脱落が見られ，脱落部より漿膜側にある粘膜固 有層の細動脈は途絶し，表面に突出した棍棒状に应 張して観察される。また同部の集合細静脈には流入 毛細血管は見られず，棍棒状に拡張している。一方 大きな脱落部の周囲の網状構造のほほ保たれている 場所では，毛細血管および毛細血管網には軽度の蛇 行像が見られ，部分的な小範囲の毛細血管網の脱落 が観察されるが，狭小化は余り著しくない。また毛 細血管の破綻に一致して大小不同の樹脂の流出が多 数観察される.

この条件下の血管変化は細動脈の拡張像で示され るごとく，jっ血性変化が優先し，破綻している毛 細血管から多数の樹脂が流出し，多量の出血を証明 する鋳型像を観察した。

ストレス負荷 6 時間後の寒体顕微鏡の観察では, ストレス負荷 3 時間後の条件下のものとほほ同じ程 度の点状あるいは線状の胃体部粘膜ビランとこれら より相当量の出血を観察した，組織標本の検索では， 粘膜固有層深部に達する粘膜損傷と同部の細胞の破 壊および粘液の流出を観察した。また粘膜下層の動 脈壁の平滑筋細胞の笔縮像を負荷 3 時間後のものと 
同じ程度に認めた。

血管鋳型の観察（図 9，10）では，広い範囲の毛 細血管網の脱落が見られ，同部に上行している細動 脈は途絶し棍棒状にうっ滞している。この細動脈の 拡張像はストレス負荷 3 時間後のものと比較すると 粘膜固有層深部に達し，正常時に見られる梯子状の 相互の分枝血管は，棍棒状に変化した細動脈には観 察されなかった，また同部の集合細静脈も途絶し棍 棒状にうっ滞して流入毛細血管は全く見られない。 また毛細血管の破綻に一致して類球状の大小不同の

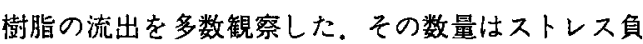
荷 3 時間後のものとほぼ同じ程度であった（図 9 ). 一方負荷 6 時間後のものの断面像を覾察すると, 細 動脈の表層での途絶と粘膜固有層深部に達する拡張 像および軽度の蛇行を観察するが，この途絶した細 動脈には分枝血管は全く見られない。また流出した 大きい類球状の樹脂を多数観察した（㘝10）.

ストレス負荷12時間後の胃粘膜の実体顕微鏡によ る観察では，ストレス負荷 6 時間後のものと比較し て胃粘膜の出血はや、減少するが，ビランはほぼ同 程度に認めた。組織標本の検索では，粘膜の損傷と 細胞の崩壊壊死および粘液の流出を負荷 6 時間後の ものとほぼ同程度に認めた．また粘膜下層の動脈壁 の平滑筋細胞の繁縮像も同じ程度に観察した。

血管鋳型の観察（図11）では，毛細血管網は広範 囲に脱落し，同部に上行している細動脈は途絶し桩 張している。同部の集合細静脈は流入毛細管を全く 欠き，拡張している像が数本突出して観察される. その周囲には毛細血管の破綻に一致して大小不同の 類球状の樹脂の流出像を多数観察した。しかしこれ らの血管変化は負荷 6 時間後のものと比較してや ， 広い範围におよんではいるが，ほほ同程度の変化で あった。またこれらの血管の周囲の毛細血管網はほ は保たれており，蛇行もあまり見られない。

ストレス負荷18時間後の胃粘膜の実体顕微鏡によ る観察での出血とビラン，組織標本の检索による粘 膜損傷と細胞の破壊および粘液の流出などの変化は 負荷12時間後のもののそれぞれの変化とほぼ同し程 度に観察された。

血管鋳型の観察（図12）では，広い範囲での毛細 血管網の脱落が見られ，同部に上行している多数の 細動脈は負荷12時間後のものと同じ程度に途絶し， 棍棒状に桩張している像を観察した。また樹脂の流 出像も多少観察されるが，負荷12時間後のものと比 較してかなり減少している，網状棈造の保たれてい
る毛細血管網はわずかに蛇行が見られ，集合細静脈 とともに軽度に拡張している。

ストレス負荷24時間後の胃粘膜の実体顕微鏡での 観察では，負荷18時間後のものと比較して出血は減 少しているが線状のビランは多数見られた，摘出胃 を水洗し粘液を除去すると線状のビランがよく観察 される（図13）.組織標本の検索では，粘膜固有層哚 部に達する粘膜の損傷と同損傷部の細胞の破壊と多 くの粘液の流出を観察した（図14）。また粘膜下層の 動脈壁の平滑筋細胞の敩縮像を他の条件下のものと 同様に観察した（図15）。

血管鋳型の観察（図16）では，広範囲に毛細血管 網は脱落し，その脱落部に上行している多数の細動 脈は粘膜固有層中部で途絶しているが，その途絶し た細動脈には拡張像が認められ，その拡張の範囲は 粘膜固有層深部に達している。しかしこの血管変化 が粘膜筋板に達する像は見られない，またこの途絶 し拡張している細動脈には分枝血管は全く見られな い．同部の集合細静脈は負荷12時間後のものに見ら れた表層に突出した像は見られず，途絶し拡張した 像が粘膜固有層媣部に達している。粘膜表層への樹 脂の流出はわずかしか観察されなかった。また網状 構造の保たれている場所の毛細血管の蛇行はあまり 観察されないが，負荷18時間のものと同じ程度の拡 張像を観察した，集合細静脈および流入毛細血管も 同樣に拡張している。

以上のように経時的な水浸拘束ストレス負荷によ る実験的急性胃瀆昜をラットに作成し，その胃粘膜 の実体顕微鏡による観察では，明らかな胃粘膜の出 血とビランをストレス負荷 2 時間後以降の条件下の もの全てに観察した。組織標本の検索では，ストレ ス負荷群の全てのものに粘膜下層の動脈壁の平滑笳 細胞の等縮像を観察した。この繁縮像はストレスを 与之た時間の長短には余り関係なく、ストレスを与 えた全てのラットにほほ同じ程度に観察された。ま た負荷 2 時間後以降のものには経時的に增加する粘 膜の脱落と同部の細胞の破壊と粘液の流出を認めた。 しかしこれらの粘膜組織の損傷は粘膜固有層深部に 達するも粘膜筋板を越えるものは見られなかった。

血管鋳型の観察では、ストレス負荷の短時間のも のは，毛細血管の著明な蛇行すなっち血管轹縮とそ れに次ぐ狭小化と先細り状の途絶および毛細血管網の 陥凹と網状棈造の脱落などの虚血性変化を観察した。 ストレス負荷の長時間のものでは，毛細血管と細動 脈および集合細静脈の途絶は增強する。また棍棒状 
のうっ㴆像とともに粘膜血管の破綻は粘膜固有層深 部へと進んだ。しかしこれら粘膜血管の破糘は粘膜 固有層内にとどまり粘膜筋板を越えるような変化は 観察されなかった。

\section{3 ）幹迷走神経切断術の影響}

幹迷切のストレス溃湟に対する予防的影響を検索 する目的で，幹迷切 1 週間後，水浸拘束ストレス負 荷 30 分, $1,2,3,6,12,18,24$ 時間後の 8 群に分 け，胃粘膜微細血管構筑の変化を観察し，併せて実 体顕微鏡による観察，組織標本の㭘索を経時的に行 なった。

幹迷切 1 週間後にストレス負荷（以下幹迷切後負 荷)したラットの何れの群でも，その胃粘膜の実体 顕微鏡による観察では，出血やビランなどの胃粘膜 変化は全く観察きれなかった．また組織標本の検索 でも，胃粘膜の損傷や細胞の破壞などの変化は観察 されなかった。しかしどの条件下のものでも同し程 度に，粘膜下首の動脈壁の平滑筋細胞の維縮像を認 めた。幹迷切後負荷24時間後の組織標本の観察（図 $25 ， 26 ） て ゙ は ，$ 粘膜の損傷は認められず，一方動脈 壁の繁縮をストレス負荷群のそれとほぼ同じ程度に 認めた。

幹辻切後負荷30分後の胃粘膜血管鋳型の観察（図 17）では，毛細血管および毛細血管網の蛇行は高度 に見られ，葉合細静眽遠位部における毛細血管に狭 小化が著るしく，毛細血管網の陥凹が軽度見られる が，血行の途絶像は全く観察されない，また集合細 静脈には拡張像が，その流入毛細血管には搪張像と 蛇行像が観察される。これらの血管変化はストレス 負荷30分後の血管鋳型像（図 3，4）と比較して, 毛細血管の途絶が見られないこと以外はほとんど差 はなかった，すなわち血管攣縮と虚血性変化はみら れるが，血行の途絶像がみられないのが特徵であった。

幹迷切後負荷 1 時間後の血管鋳型の観察（図18） では，毛細血管の蛇行像と狭小化およびときに先細 り状の途絶を観察し，毛細血管網の蛇行と軽度陥凹 が見られ，また集合細静脈とその流入毛細血管の著 明に搪張した像を観察した。しかしストレス負荷 1 時間後のもの（図 5 ）に見られた毛細血管網の脱落 はほとんど観察されなかった。

幹迷切後負荷 2 時間後の血管鋳型の観察（図19, 20）では，毛細血管の㹨小化は著明となり，先細り 状の血行の途絶が相当数見られるようになる。また 毛細血管網には部分的宿凹が見られるが、しかし網 状構造の脱落はほとんど見られない，また集合細静
脈とその流入毛細血管には搪張像が認められる（図 19）。なお同条件下のものの中には, 毛細血管の途絶 が著明で，毛細血管網の表層での網状粠造の部分的 脱落が観察されるものもあった（図20).しかし全般 的にみると，对照群のストレス負荷 2 時間後のもの （図6，7）と比較して毛細血管の血行の途絶や毛細 血管網の脱落ははるかに少なく，簛囲も部分的であ $\eta$ ，粘膜表層にとどまり，打ち报き像のごとき脱落 は観察されない，また小球状の樹脂の流出は全く観 察されない。

幹迷切後負荷 3 時間後の血管鋳型の観察（図21） では，毛細血管および毛細血管網は軽度蛇行を示し， 全体にほほ均一な㹟小化が見られ，先細りの血行 の途絶と網状棈造の陥凹と部分的脱落が軽度観察さ れる。しかしこれらの血管変化はストレス負街 3 時 間後のもの（图８）飞比較すると，その程度はかな り軽度で，途絶し搪張して棍棒状にうっ滞した細動 脈は全く見られず，むしろわずかではあるが侠小化 が見られた．また集合細静脈とその流入毛細血管に 搪張像は見られるが，棍棒状のうっ滞像は見られな い. 毛細血管の破綻に一致して観察された樹脂の流 出も全く観察されない.

幹迷切後負荷 6 時間後の血管鋳型の観察（图22） では，毛細血管の狭小化はさらに著明となり，先細 り状の血行の途絶はや、多く見られ、毛細血管網の 翓凹がや，広い範囲で，また部分的網状構造の脱落 が多少観察される。また毛細血管と毛細血管網の蛇 行を軽度ながら観察した。しかし対照群のストレス 負荷 6 時間後のもの（図 $9 ， 10 ） に$ 見られた棍棒状 にうっ膟した細動脈や類球状の樹脂の流出は観察さ れず, 幹迷切後負荷 6 時間後のものの血管変化は極 めてわずかであるといえる。

幹迷切後負荷12時間後の血管鋳型の観察（図23） では，毛細血管には狭小化と途絶が，毛細血管網に は部分的網状構造の脱落が比較的少ないが観察され， 集合細静脈とその流入毛細血管には高度に搪張した 像が見られる。また流入毛細血管には蛇行を著明に 認めるが，毛細血管にはわずかの蛇行しか見られず， 毛細血管網には小範囲の宿凹がわずかに見られるに すぎない，对照群のストレス負荷12時間後のもの(図 11）に見られた毛細血管網の広範囲の脱落と同部に 上行している細動脈の途絶および流入毛細血管を欠 き拡張している集合細静脈の突出像, あるいは類球 状の樹脂の流出などは全く観察されない。

幹迷切後負荷18時間後の血管鋳型の観察（図24） 
では，毛細血管の狭小化と先細り状の途絶および毛 細血管網の部分的網状棒造の脱落がかなり観察され る. しかしその血管変化は粘膜固有層最表層におけ る変化にすぎず，对照群のストレス負荷18時間後の もの（図12）に見られた途絶し，棍棒状に拡張した 細動脈あるいは類球状の樹脂の流出は全く観察され ない。また集合細静脈と流入毛細血管の搪張した像 もほとんど観察されない。

幹迷切後負荷24時間後の血管鋳型の観察（図27） では，毛細血管には軽度の蛇行と狭小化が見られ， 毛細血管網の一部には部分的網状構造の脱落が，ま た一部には小範囲の網状構造の陥凹が見られる。そ の網状構造の宿凹の一つには輪状に見られ，その中 央部に網状構造の脱落と細動脈の表層での途絶が観 察される。この細動脈の途絶は表層の浅い位置での み見られ，軽度の拡張が観察される．また散在性に 小球状の樹脂の流出が極めてわずかではあるが観察 される.これらの血管変化は何れも粘膜最表層にお いて観察され，对照群のストレス負荷24時間後のも の（図16）に見られた細動脈の粘膜固有首中部にお ける途絶と粘膜固有層深部に達する拡張像は全く観 察されなかった。

以上の観察所見のごとく，幹迷切後ストレス負荷 後における胃粘膜微細血管変化は上記何れの条件下 においても毛細血管の蛇行と狭小化および先細り状 の途絶，毛細血管網の軽度陥凹と部分的網状構造の 脱落，細動脈の粘膜最表層での途䋓等，すなわち粘 膜固有層表層血管の變縮と虚血性変化であった。そ してその血管変化の経時的な進行は涂り観察されず， またうっ血性変化は全く見られなかった。しかし对 照群のストレス負荷群と比較すると幹迷切を行った 群では，粘膜血管の変化は少なく，血管変化のおよ ふ心範囲も浅く粘膜固有層最表層にとどまるにすぎな かった.

すなわち幹迷切後ストレス負荷群では，血管紧縮 と虚血性変化を観察したが,これら粘膜血管変化の 経時的進展は非常に少なく，ストレス負荷群のよう な完全な血行途絶による粘膜血管網の脱落や同部に 上行する細動脈のうっ滞等の変化は全く見られず, 血流の面よりみても幹迷切がストレス清㰾発生に对 して不完全ではあるが予防的効果が認められた。

4）ストレス負荷後の自然治离傾向

ストレス償瘍の治痖経過は早く，肉眼的，組織学 的にも数日にして治療するが、今回はこの治篜過程 における微細血管構筑の再生修膘過程を検討した。
すなわち水浸拘束ストレス負荷 2 時間後，24時間後， 直ちにストレスを解除し，その後の治虑過程を血管 再生の面より観察し，併せて実体顕微鏡による観察 と組織標本の検索を行なった。

ストレス 2 時間負荷後 24 時間放置群の実体顕微鏡 の観察では，わずかの粘膜出血と浅いビランを認め た。組織標本の検索では，表層粘膜の損傷を認めた が、粘膜下層の動脈壁の平滑筋細胞の攀縮像は観察 されなかった。

胃粘膜血管鋳型の観察（図28，29）では，毛細血 管の途絶と毛細血管網の小範囲の脱落が見られ，同 部に上行している細動脈にも途絶が見られる。この 途絶している毛細血管と細動脈の先端にはしばしば Y 状に発芽生長した血管像を観察した（図28）。その 拡大像では，発芽した血管が互に接近している像も 観察される（図29）。しかしストレス負荷時に見られ た毛細血管の蛇行や狭小化あるいは拡張した像，ま た集合細静脈と流入毛細血管の应張像などは観察さ れなかった。

ストレス24時間負荷後48時間放置群の実体顕微鏡 の観察では，軽度の粘膜出血と浅いビランを認めた。 組織標本の検索では，浅い粘膜表層の損傷と少数の 粘膜細胞の崩壊を見るが，粘膜下首の動脈壁の平滑 筋細胞の攀縮像は観察されなかった。

血管鋳型の観察（図30，31）では、ストレス溑㴦 の形成された粘膜部は広範囲に毛細血管網の脱落が あり，健常部に比較し陥凹が見られる．同部の途絶 した細動脈には粘膜表層に向かう不規則な発芽像が 観察され，また途絶した集合細静脈にも同様の不規 則な発芽像が観察される（図30）。この発芽血管の应 大像を藓察すると，不規則で不正形のコブの様に見 える（図31）。しかしこの時期では発芽血管は互の連 絡は見られず，網状構造も全く形成されていない。 また再生途上の細動脈と集合細静脈の拡張像などは 観察されない.

ストレス24時間負荷後120時間放置群の実体湿微鏡 の観察では，粘膜出血およびビランはほとんど観察 されない，組織標本の検索では，極めて浅い表層の 粘膜損傷と極くわずかの細胞の破壊および少量の粘 液の流出が観察される。

血管鋳型の観察（図32．33）では，再生血管部は 全体的になお宿凹しており，網状構造を有した周囲の 健常部との境界は明瞭に確認される。再生細動脈お よび再生集合細静脈は不規則に蛇行しながら上行し， 表層でも蛇行が見られる。この再生細動脈は表層に 
達するまで，相互間の分枝吻合血管が見られない。 しかし表層では不規則に連絡している血管像が観察 されるが，未だ網状構造は不完全である。集合細静 脈も不規則に上行再生しているが, 細動脈との連絡 は不十分である。

以上の観察結果のごとく，毛細血管領域での損傷 血管の再生は途絶血管がしばしばY状に発芽し，互 に進展して接近し吻合しあう。細動脈領域での途絶 血管の再生は分枝血管を持たず不規則に蛇行しなが ら上行し，表層で互に吻合している。このように毛 細血管，細動脈，集合細静脈は発芽し再生され，互 に吻合してほほ正常時に近い粘膜血管が再生される 像を観察した。

\section{考宩および総括}

急性胃潰瘍発生の要因と胃粘膜の血行動態との関 連およびこれに对する迷切の影響等を明らかにする 目的で，1）ラット正常胃の微細血管構築，2）実 鈳的ストレス瀆瘍，3) 幹迷走神経切断術の影響，

4) ストレス負荷後の自然治㾍傾向について, メル コックス樹脂注入による血管鋳型法により，それぞ れの胃粘膜微細血管鋳型を作製して三次元的にその 形態像をSEM で観察した。またそれぞれの检体の 実体顕微鏡による観察と組織標本の検索を併せて行 なった。

\section{1) ラット正常胃の微細血管構築}

ストレス潰瘍は腺胃部とくに胃体部に発生すると いわれている，著者の実験観察においてもとくに腺 胃体部にストレス潰瘍すなわち胃粘膜出血およびビ ランを確認した。そこでまずラット正常時の腺胃体 部の粘膜微細血管構築について検討した。

正常胃の血管構勧について Nylander ${ }^{15)}$ は血管造 影法を用いて，Hase ${ }^{16)}$ は墨汁注入法を用いてそれぞ れ報告しているが，その微細棈造にはなお不明な点 が多い。高尾 ${ }^{17)}$ ，小林 ${ }^{18)}$ らは血管鋳型法により胃粘 膜微細血管構築について詳細な報告をした。

著者の実験観察の結果, 正常腺胃体部粘膜の微細 血管構築は諸家の報告とほぼ一致していた。すなわ ち粘膜下血管網より枝分れした細動脈は粘膜筋板を 貫き，互に分枝を出し連絡を持ちながら直線的に上 行し，粘膜最表層で類円形の網状構造すなわち毛細 血管網を形成していた，次いで集合細静脈へと流入 し，これは粘膜固有層内を全く分枝を持たず直綄的 に下行して粘膜筋板を貫通して粘膜下血管網に属す る果合静脈へほぼ直角に移行していた。このように
正常時の腺胃体部粘膜血管は走行，配列，血管の太 さ等が規則正しく，豊富な血管網を有していた。こ の規則正しい血管網を保持していることが胃粘膜の 正常活動を保つうえで重要なことと考えられる。

2 ) 実験的ストレス瀢富

胃溃瘍発生の機序に関して，古くは Rokitansky ${ }^{8)}$ の神経障害説, Bergmann ${ }^{5)} の$ 自律神経失調説, $\mathrm{Cu}-$ shing ${ }^{19)} の$ 副交感神経中枢刺激説, Dragstedt ${ }^{20)} の$ 胃 液分泌の神経支配に関する研究などの副交感神経中 枢刺激優位の諸説が主体であったが, Virchow ${ }^{4}$, Boles $^{21)}$, Watts ${ }^{22)}$, Selye ${ }^{9)}$ 等により交感神経刺激に よる循環障害を重要視する報告が発表された。最近 に至り，並木 ${ }^{23}$ は水浸拘束ストレス負荷方法により， 松尾 ${ }^{24)}$ は前頭葉眼窩後面後部皮質の電気刺激実験に よりストレス潰渲発生機序について，ストレス刺激 が大脳皮質から視床下部へと伝わり, 副交感神経系, 交感神経系，下垂体・副督系の3つの経路を介して 胃に働き，結局攻慗因子を強め，防禦因子を弱める といった両方の働きかけによる総合的効果により急 速に潰湯性変化の発生をみると報告している，その 中でも防禦因子の問題とくに交感神経刺激による血 流障害に基づく粘膜抵抗の減弱を重要視している。 Brodie $^{25)}$ は水浸拘束による胃出血は血流障害との関 係の重要性について交感神経系の経路を重要視して いる。一方 Hübner ${ }^{26)}$ は拘束下のラット胃の粘膜下 動脈壁の平滑筋細胞の㲗縮像を観察し，それ自身に より循環障害をおこして粘膜は損傷をうけると報告 している．服部 ${ }^{27}$ は水浸拘束ストレス負荷後すべて の胃粘膜に出血あるいはビラン性変化が起こり，そ れと共に粘膜および粘膜下層の卹管の中膜平滑筋細 胞に多数の周核空胞の出現を認め，交感神経中枢の 刺激により血管彎樎をきたし、これに起因して粘膜 病変をもたらすと報告している。また松岡28らも拘 束ストレス負荷ラットの腺胃粘膜下動脈の中膜に周 核空胞の出現を認め, 動脈熨縮の急性期変化である と報告している。この動脈壁の周核空胞は動脈彎縮 の組織学的根拠にあげられ，竹内 ${ }^{29)}$ が腎動脈繁縮実 験で記载し，血管絵縮の結果としてその血管壁中膜 に出現する形態学的特徵とされている，諸家はいす れも交感神経系の経路を重要視し，血管路縮がス卜 レス漬曒の成因と非常に関係が深いことを報告した。 そこで著者の実験観察をみると，ストレス負荷群 の全ての条件下のものの組織標本で粘膜下動脈壁の 平滑筋細胞に塱縮像を観察した。また血管鋳型像に おいても正常胃では見られなかった毛細血管の蛇行 
像を観察し、この蛇行像はストレス負荷30分後のも のにおいて最も著明に認めた。この血管の蛇行像は 血管爰䑾を三次元的に形態像として観察しえたもの と考える．著者の実験においても諸家の報告とほぼ 一致しており，交感神経刺激による血管摹䌅がスト レス潰瘍発生の下地をつくる因子と考えられる。

Hase $^{16)}$ らは墨汁注入法による観察で,拘束下のラ ッ卜霄粘膜の細動脈の粰縮に起因して虚血性変化を きたし，その連続性により胃粘膜局所の虚血状態が 引きがねとなって組織は損倠をうけストレス䟺晹が 生じると報告している。毛利 ${ }^{30}$ は冷水拘束ストレス 負荷実験で弱いストレスを負荷したラットの血管造 影法による観察で，粘膜面に分布する細動脈と毛細 血管に立影像が得られず，乏血を示す場合が多く， 粘膜表面での血管の断裂像および充影剤の流出を認 め，この乏血性変化は胃粘膜全体におよびストレス 刺激による直接的反応であると考えている。また杉 町 ${ }^{311}$ は色のマイクロフィルム注入法で， 3 時間 4 ${ }^{\circ} \mathrm{C}$ 泠室拘束によるストレス負荷により多数の浅い出 血を伴なった急性溑瘍が発生し，しかも胃粘膜の毛 細血管に狭小化が起っており、マイクロフィルムが 侵入しにくいことを明らかにし，この粘膜のそ血性

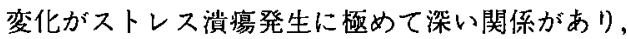
また漬颌からの出血は動静脈両側から起っていて， 胃壁の血管変化は潰瘍の結果ではなく，むしろ原因 であると報告した。

著者の実験観察においてストレス負荷30分後すで に毛細血管の狭小化と先細り状の途絶および毛細血 管網の陥凹などの胃粘膜血管の虚血性変化を観察し 次いで負荷 1 時間， 2 時間後のものには虚血性変化 がさらに進み毛細血管網の部分的脱落を観察した。 この胃粘膜の虚血性変化は胃粘膜抵抗を減弱にして 粘膜損倠を苍起すると考えられ、諸家の報告と同様 に血管繁縮に起因する虚血性変化は粘膜組織を壊死 に導き，ストレス溃瘍発生におよぼす重要な因子で あると考えている。

次いで毛利 30 は冷水拘束負荷実験で，ストレスを 強くすると粘膜のそ血所見は局所的となり，さらに 強くなるが，粘膜損复をおこした部分の周囲にある 血管はそ血状態とは反対の充血状態を呈し，この部 分の粘膜血管像は血管数が密である感じを抱かせ， 細い血管も太くなり充血状態を助長している像を観 察し，粘膜表面の保護的作用が低下すると解してい る. Hase ${ }^{16)}$ は拘束負荷 4,6 時間後のラット胃粘膜 に虚血性変化とうっ血性変化が不規則に混在するが
一般的にはうっ血性変化の方が明瞭であり，血管損 傷の大きい部分はうっ血した血管に囲まれていると 報告している，穴戸 ${ }^{32}$ は色素注入法により 3 時間拘 束後の毛細血管に搪張像を認め，また血管周囲に著 明な色素の漏出を認めて血管壁の透過性の元進を証 明した。 Guth ${ }^{33)}$ らは拘束ストレス負荷 3 時間後に おいて明らかな粘膜の脱落はなく，粘膜および粘膜 下組織の血管拡張と浮腫が著明で粘膜全層にわたり 漏出性出血の所見を認め，さらに拘束24時間後では 粘膜は罗死に陥り脱落しているが粘膜筋板まで達す る病変は見られなかったと報告している。

著者の本実験における組織標本の観察で，負荷 2 時間後より明らかな粘膜損傷を認め，負荷時間の増 加と共に粘膜固有層深部へと達する所見を認めた。 しかし24時閒負荷しても粘膜筋板を越える深い粘膜 損傷は観察されず，これ等の点では諸家の報告と一 致をみた，血管鋳型の観察では，負荷 2 時間後のも のには虚血性変化の進行した像を見せる標本とうっ 血性変化を見せる標本とが観察されたが，負荷 3 時 間後のものより負荷時間の增加と共に゙細動脈および 集合細静脈の途絶と棍棒状にうっ滞した像は増大し, 負荷24時間後のものにはその血管変化は粘膜固有層 媣部に達しうっ滞も高度となっていた。しかしこ の血管変化も粘膜損鹪と同じく粘膜固有層の範囲に とどまり粘膜筋板を越える病変は観察されなかった。 このうっ血性変化をきたした部分の粘膜組織は脱落 して粘膜ビランを形成するものと思われる。

Barclay6), Barlow ${ }^{7)}$ らは血管造影法を用いてヒト の胃の粘膜下層に動静脈吻合の存在を観察した。し かし動静脈吻合の機能に関する報告はあまり見られ ず，またその報告も推論の域を出ていないが，胃粘 膜循環の調節に重要な役割りを演しているであろう

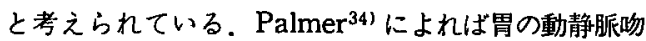
合は、ときに 5 倍の太さにも拡大し得るので粘膜血 流を急速に変動させる可能性がある、したがって病 的な吻合血管の開閉の異常は粘膜の傷害を起こし得 るが，単なる虚血よりも血流の少ないうっ血の方が ビランへ発展しやすいと考えている，小林 ${ }^{35}$ は色素 注入法による観察で，動静脈吻合はアドレナリン投 与により開大し，七スタミン投与により収緶傾向が 見られると報告している。浅見 ${ }^{36)}$ は二重色素注入法 および微小血管造影法により，実体顕微鏡下で粘膜 下組織に動静脈吻合を観察し，ガラス球注入法の応 用で動静脈吻合の機能的役割について，生理的には ある程度微小循環を受動的に調節するものと思われ 
るが、粘膜血流を遮断するほどの流量は受容し得な いと考えているが詳細は不明な点が多いと報告して

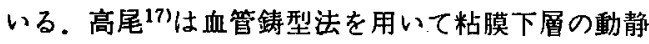
脈吻合を観察し，弁等の開閉機構を有さない事を報 告しているが,その機能解明は出来ていない.

本実験において毛細血管あるいは細動脈が途絶を きたしたにも拘らず，その近位の集合細静脈には樹 脂が十分注入されていた。 また負荷早期には途絶血 管のうっ帯した像は観察されないか，負荷後期には 途絶した細静脈と集合細静脈のうっ滞像を観察した。 これらの粘膜血管の変化には粘膜の血流が粘膜下血 管網一細動脈一毛細血管網一集合細静脈一集合静脈 の経路のみでは理解が困難であり，他の経路すなわ ち粘膜下層にある動静脈吻合の関与が十分推察され るが，血管鋳型法の観察ではその機能の解明に関し て十分な検索は出来なかった。

ストレス潰湯発生要因について，Leonard ${ }^{37)} ら は$ ストレス初期ではまず交感神経の興蹒が見られ，血 管の収縮を起こし胃粘膜の虚血をもたらす，その後 副交感神経系の興䠓が起こり，胃の血流が増し，同 時に酸・ペプシン分泌が増し，すでに脆弱になって いる胃粘膜が侵され潰瘍が発生すると述べている。 並木 ${ }^{23}$ は交感神経系の與奮により細動脈の収縮や動 静脈吻合の開放が起こり胃粘膜は虚血状態となる。 また静脈側の収縮によりうっ血が起こり粘膜先端に 血栓形成をみ，いっそう血流障害が強まり胃粘膜は 脆弱となる。一方副交感神経系の與䍑は迷走神経を 介して攻撃因子を增強し，また胃の運動と緊張の亢 進をきたす。これにより胃壁の筋層が痙紫性に収綃 し，そのため粘膜を貫く血管が強く圧迫を受け粘膜 の血流障害が起こり虚血を助長して粘膜抵抗性は弱 まる。ここへ胃液の作用が加わり障害を受けた胃粘 膜組織から血管作働性物質が遊離され，これがさら に虚血を助長するといった悪循環も生じてくる。ま

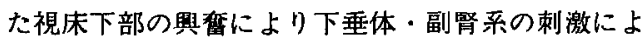
り攻慗因子が増強する．要するにこれらのことがか らんでストレスによる潰痹性変化の発生をみると報 告している。

本実験において水浸拘束ストレス負荷時の粘膜損 傷の程度と交感神経刺激による胃粘膜循環障害に関 して観察検討したが,これだけではストレス潰瘍の発生 機序を説明するには不十分である.しかし著者は胃粘膜 血管絙縮に始まる胃粘膜微細循㨽障害により胃粘膜組織 は壊死あるいは壊死におちいりやすい状悲となり，同時 に他の胃粘膜防缶因子も弱まり，その上攻撃因子が增強
し、それらの総合的作用によりついには粘膜組織は損傷 をきたしてストレス測痬が発生するものと考えている. 3 ) 幹迷走神経切断術の影響

崸瘍発生の成因に攻撃因子としての胃液の塩酸お よびペプシンの作用，とくに迷走神経を介する刺激 の影響を優位とする考えは多くの学者により報告さ れてきた．Rokitansky ${ }^{8)}$ は迷走神経の機能異常と胃 液酸度の亢進によって峘瘍が発生すると述べ, Dragstedt ${ }^{20)}$ は胃溃痩は迷走神経における胃分泌および運 動繊維の緊張によるものであると報告した，Brodie ${ }^{38)}$ は拘束溃瘍の発生に関して迷切により胃液分泌量か 減少し，瀕瘍の発生を減少させるが完全には抑制し ないと報告した。鳥海 ${ }^{39}$ は雨側迷切施行後，光と音 および電気刺激を同時に加えるストレス負荷で，肉 眼的観察では全例に出血，ビラン，潰痬などの変化 が見られず、組織像にもとくに変った点を見なかっ たとし，迷切により渻瘍発生が抑制される点からみ て，ストレス瀕瘍発生においては，胃における迷走 神経支配が体液性支配よりも優越するものと考えて いる. Cushing ${ }^{19)}$, Shay ${ }^{40)}$ その他多くの研究者が迷 走神経と胃液分泌に関する報告をしているが，その ほとんどが迷切による胃液分泌の抑制，減酸効果が ストレス䟺演発生を防止すると考之ている。しかし 迷切の血管系や血流におよぼす影響の研究は少ない。 迷切の胃粘膜血流への影響に関して, Matsumoto ${ }^{411}$ は迷切は急激に粘膜表層の血流を低下させ，擦過に よるびまん性出血を減少させると報告し，川村42)は 粘膜血流を交刃熟電対法で測定し，迷走神経の機械 的および電気的刺激にて胃体部粘膜血流は增加し， それと平行して胃酸分泌は六進しており，幹迷切後 胃体部の血流は一過性の上昇後下降しはじめ，32分 後37士6\%の血流減少を認めて出血㵅瘍に対して直 接有効に作用することを推定している。毛利 ${ }^{30}$ は片 側迷切後冷水拘束ストレス負荷実験で，片側迷切側 胃粘膜には充血および潰瘍の発現は見られず、非迷 切側胃粘膜には潰暘が発現してくると報告し、この 事実は迷走神経が胃液分泌機棈を抑制しているだけ でなく胃血流動態支配に密接に関与していることを 示唆すると考えている，また Sullivan ${ }^{43)}$ は迷切がス トレス潰瘍に有効なのは，迷切により粘膜下に存在 する動静脈吻合が作動して粘膜の虚血が起こるため と考えた。 Nylander ${ }^{15)} ら は ，$ 血管造影法を用いて迷 切後の血管棈筑を観察し，小動脈と細動脈は非常に まばらでほとんど見られないが，集合細静脈は十分 に見られると報告している。 
著者の観察結果において, 幹迷切のみでは正常時 に比較してとくに毛細血管の狭小化が著るしく観察 された。これは幹迷切により血流減少が招来した結 果と考えられる。また幹迷切後ストレス負荷群にお いて，全条件下のものに幹迷切による毛細血管の狭 小化が観察されたが，毛細血管の途絶と樹脂の流出 はほとんど観察されなかった。この幹迷切による毛 細血管の狭小化と出血をほとんど防止させる事実は， 前述した幹迷切後胃粘膜の血流減少を来たすという 諸家の報告と一致をみる．また全条件下のものに毛 細血管網の陥凹および部分的脱落などもわずかに観 察したが，その血管損傷の程度は極く軽度で粘膜表 層の範囲における損傷にすぎなかった。そして途絶 血管には搪張した像すなわちうっ血性変化は全く観 察されなかった。これら血管変化とくに血行の途絶 とうっ血性変化の抑制は幹迷切群に明らかに観察さ れ，幹迷切がストレス潰痛抑制に有効であることを胃 粘膜微細血管構築の面より証明しえた。すなわち幹 迷切のストレス負荷におよばす影響は, Dragstedt ${ }^{201}$ 以来認められている迷切による減酸効果ばかりでな く，粘膜の血流減少を招来して血行の途絶とうっ血 性変化の抑制であるといえる.

松尾 ${ }^{24)}$ は前頭葉眼窩面後部刺激により，胃の運動 六進の出現と同時に血流が停止する現象を認めたが, 内㼨神経切断後の同刺激により胃の運動六進の出現 は認められるが血流の変化は出現せず，前頭桇眼䆟 面後部刺激は迷走神経と内臓神経を通って，前者は 胃運動立進，後者は血管㝈縮を起こさせることを証 明し，ストレス償洦発生は交感神経刺激によるいわ ゆる機能的な血管攀縮が出現し，一方迷走神経刺激 による胃運動および胃夜分泌充進が加わって潰瘍が 成立するのであろうと報告している。

著者は幹迷切後ストレス負荷群の全条件下の組織

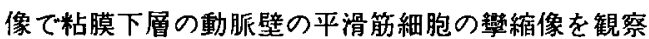
し，血管鋳型の観察では毛細血管および毛細血管網 の蛇行像を観察した。これはストレス負荷により血 管等絔が出現したもので，迷走神経の遮断にも拘ら ず血管擊縮を来たした事実は交感神経系が有意に関 与したことを裹づける証拠と考えられる。

以上よりストレス潰演の発生に関して，交感神経 刺激が有意に関与して毛細血管の䘘縮を来たして虚 血性変化を招来し，次いで粘膜血管のうっ血性変化 が加わり防禦因子の抵抗減弱を来たす。一方攻撃因 子の增強により血管損傷が増強し出血が見られるよ うになり，粘膜組織は壤死に陷スり脱落してビラン
が引き起こされるのであろうと考えられる，また本 研究では検索しなかった胃粘膜関門の問題, 副腎系 の関与など綕合的に影響しているものと思われる.

4 ）ストレス負荷後の自然治療傾向

ストレス潰瘍は早期に治療してしまうため，治滤 過程を検索した報告は少ない。岡部 ${ }^{13)}$ はその自然治 瘾を観察した結果，水浸拘束によるストレス潰瘍は 2ー3 日後からビランは消失し, 粘膜の欠損のみ認 められ，約20～28日目には完全に治療して，㾮痕化 は見られなかったと報告している．水島44)らは水浸 拘束によるストレス潰瘍は非常に治りやすく，4一 5 日でほとんど治瘾してしまい，ストレス解除 3 日 後すでに潰瘍辺縁より再生上皮がのびはじめ，4 日 後には潰瘍底を一層の再生上皮が覆い，組織学的に 洀痕の所見を呈すると報告している。並木 ${ }^{45}$ は精神 的ストレスが自律神経への影響を介して胃の痤を ひき起こし、これによって胃壁の筋層を貫いて粘膜 に至る血管が強く圧迫をうけたり，さらに血管自体 の急激な攀縮が起こり，結局はかなり広い範囲の胃 粘膜に血行障害が惹起され，潰瘍発生の下地をつぐ ることがストレス潰瘍の大きな原因と考え，そして これらの縮は一過性であり，そう長くは続くもの ではないから、これによって生した漬瘍性変化の治 りもまた早いのであろうと考えそそしてこのように 血管性の因子を考虑するとき，ストレス潰瘍が急性 に多発し，しかもそれが短時日に消失するといった 理由の説明がつけやすいと報告している．

本実験において，ストレス負荷解除後には毛細血管， 毛細血管網および粘膜下血管の酕縮像は観察されな かった．著者はこの血管摾縮の消失により，虚血性 変化拉よU゙うっ血性変化は共に消失し，次いで潰瘍 部に接する血管よりの発芽が現われ，生長して粘膜 血管の再生が完成するものと考えた，またこの再生 血管より粘膜組織は栄養をうけ，粘膜の再生が十分 起こり，傊粘膜が急速に修覆するのであろうと考 えている.

結語

急性胃瀆湟の発生要因と胃粘膜の血流上の変化と の関係を明らかにする目的で，ラットに水浸拘束ス トレス負荷を加えてストレス潰瘍を作成し，胃粘膜 微細血管構築の経時的変化と幹迷切の胃粘膜血流に およぼす予防的影響およびストレス負荷後の自然治 瘾傾向の微細血管再生をメルコックス樹脂注入法に よりそれぞれの血管鋳型を作製して SEM で観察し 
た.さらに実体顕微鏡による観察と組織標本の検索 を併せて行ない次の結果を得た。

1) 実体顕微鏡による観察で，ストレス負荷 2 時間 後以降の条件下に明らかな胃粘膜出血と点状あるい は線状のビランを認めた。

2 ) 組織標本の検索で，ストレス負荷群の全条件下 に粘膜下層の動脈壁の平滑筋細胞に路縮像を認めた。 またストレス負荷 2 時間後以降の条件下に粘膜の脱 落と同部の細胞の破䔞および粘液の流出を観察した が,この粘膜損偒は粘膜固有層内にとどまっていた。 3）血管鋳型の観察で、ストレス負荷後の全ての条 件下の毛細血管および毛細血管網に蛇行像すなわち 血管等摍像を観察し，とくに負荷30分後の条件下の ものに著明であった。

4 ）ストレス負荷短時間のものは, 血管熊縮につい で, 毛細血管の狭小化と先細り状の途絶, 毛細血管 網の陷凹と網状構造の脱落および細動脈の途絶すな わち虚血性変化を観察した。

5 ）ストレス負荷長時間のものは，虚血性変化につ いで，細動脈と集合細静脈の棍棒状に拡張してうっ 滞した像すなわちうっ血性変化と樹脂の流出を観察 した.しかしこの血管変化は粘膜固有層内にとどま っていた。

6 ）実体顕微鏡による観察で，幹迷切後ストレス負 荷群の全ての条件下の胃粘膜に出血およびビランは 全く観察されなかった。

7 ) 組織標本の検索で, 幹迷切後ストレス負荷群の 全ての条件下の粘膜下層の血管壁の平滑筋細胞の嶈 樎像を観察した。しかし粘膜損傷は全く見られなか った。

8）血管鋳型の観察で, 幹迷切後ストレス負荷群の 全ての条件下の毛細血管と毛細血管網に蛇行像すな わち血管彎縮像を観察した。次いで毛細血管の㹨小 化と軽度の途絶，毛細血管網の軽度陥凹と網状棈造 の部分的脱落すなわち虚血性変化を観察した。しかし
血行の途絶は極めてわずかであり, うっ血性変化あ るいは樹脂の流出は観察されなかった。

9 ）ストレス負荷 2 時間後24時間放置群においては, 途絶した毛細血管にしばしばY状にみられる再生血 管を観察した。この再生血管には互に接近している 像も見られた。

10）ストレス負荷24時間後48時間放置群においては, 途絶した細動脈と集合細静脈に粘膜表層に向かう新 生された不規則で不正形のコブ様の発牙血管を観察 した.

11）ストレス負荷24時間後120時間放置群においては, 再生細動脈と再生集合細静脈は不規則に蛇行しながら 粘膜表層に向かって上行していた。この再生細動脈 は互の分枝吻合血管を持っていないか，粘膜表層て は不規則に連絡している像を観察した。

12）以上の所見より，胃粘膜血管䍃縮に始まる胃粘 膜微細循環障害により胃粘膜組織は脆弱となり，そ の上攻轻因子も加わり粘膜組織は損傷をきたしてス トレス潰瘍が発生するものと考えられた。

幹迷切は粘膜の血流減少を招来し，血行の途絶と うっ血性変化を抑制することによりストレス潰湯の 発生を不完全ではあるが抑制すると考えられた。

ストレス潰瘍部の再生は，溃痬部に接する血管よ クの発芽が現われ，生長して粘膜血管の再生が完成 し，この再生血管より粘膜組織は栄養をうけ粘膜の 再生が起こり粘膜が急速に修覆すると考えられた。

\section{謝辞}

稿を終るにのぞみ、御孯篤なる御指導、御校閲を睗わ つた折田薰三教授に感謝を捧げるとともに，本研究を直 接御指導下さった高知医科大学第 1 外科教室緒方卓郎教 授に深謝致します。

本諭文の要旨は、第 7 回日本消化器外科学会, 第10回 日本臨床電子颢微鏡学会, 第20回日本消化器病学会にお いて発表した。

\section{文献}

1. 並木正義：急性胃病変の臨床一心召部痛の面から一, 胃と腸，8，9-16, 1973.

2. 川井啓一, 赤坂裕三, 木本邦彦, 日高 硬, 山口勝道, 須藤洋昌: 急性胃病変の臨床一胃出血の面から一, 胃と腸，8，17-23，1973.

3. 長山健夫，横山泰久：急性胃滇瘍の病理。胃と腸，13，169-176, 1978 .

4. Virchow, R:: Historisches, Kritisches und Positives zur Lehre der Unterleibsaffektionen. Arch. Pathol. Anat. 5, 281-375, 1853. 
5. Bergmann, G.: Das spasmogene ulcus pepticum. Münch. Med. Wschs. 60, 169-174, 1913.

6. Barclay, A.E., Bentley, F.H.: The vascularization of the human stomach. A preliminary note on the shunting effect of trauma. Br. J. Radiol. 22, $62,1949$.

7. Barlow, T.E., Bentley, F.H., Walder, D.N.: Arteries, veins and arteriovenous anastomosis in the human stomach. Surg. Gynec. Obst. 93, 657-671, 1951.

8. Rokitansky, C.A.: Mannal for pathological anatomy. London Syndenham soc. 2, 22, 1849.

9. Selye, H.: A syndrome produced by diverse nocuous agents. Nature 138, 32, 1936.

10. Rossi, G., Bonfils, S., Liefooghe, G. and Lambling, A.: Technique nouvelle pour produire des ulcérations gastriques chez le Rat blanc: I' ulcére de contrainte. Com. Ren. Soc. Biol. 150, 2124-2126, 1956.

11. Bonfils, S., Rossi, G., Liefooghe, G. and Lambling, A.: Les ulcérations gastriques de contrainete du rat blanc. Rev. Franc. Etud. Clin. Biol. 3, 703-704, 1958.

12. Takagi, $\mathrm{K}$. and Okabe, $\mathrm{S}$.: The effects of drugs on the production and recovery processes of the stress ulcer in rats. Jpn. J. Pharmacol. 18, 9-18, 1968.

13. 岡部 進、竹内孝治, 高木敬次郎：ストレス潰湟, 実駼潰瘍, 丸善, 東京, pp. 25-33，1976.

14. T. Murakami, Application of the scanning electron microscope to the study of the fine distribution of the blood vessels. Arch. Histol. Jpn. 32, 445-454, 1971.

15. Nylander, G. and Olerud, S.: The vascular pattern of the gastric mucosa of the rat following vagotomy. Surg. Gynec. Odst. 112, 475-480, 1961.

16. Hase, T. and Moss, B.J.: Microvascular changes of gastric mucosa in the development of stress ulcer in rats. Gastroenterology 65, 224-234, 1973.

17. 高尾正彦，松山正春，緒方卓郎：血管鋳型法によるラッテ胃の血管構筑の走查電子顕微鏡的観察。医学の あゆみ，97，613-614，1976.

18. 小林顕彦，竹田涁一，服部誠一，郡 大裕，服部隆則，川井啓市：胃粘膜の血管構筑に関する研究一胃底 腺領域と幽門腺領域の微細血管構築について一，日消誌，73，169-178，1976。

19. Cushing, H.: Peptic ulcers and the interbrain. Surg. Gynec. Obst. 55, 1-33, 1932.

20. Dragstedt, L.R., Palmer, W.L., Schafer, P.W. and Hodges, P.C.: Supradiaphragmatic section of vogus nerves in treatment of duodenal and gastric ulcers. Gastroenterology 3, 450, 1944.

21. Boles, R.S. and Rigges, H.E.: Neurogenic factors in the production of acute gastric ulcer. J. Am. Med. Assoc. 115, 1771-1773, 1932.

22. Watts, J.W. and Fulton, J.J.: The effects of the hypothalamus upon the gastrointestinal tract in monkeys. Ann. Surg. 11, 363-372, 1935.

23. 並木正義：急性胃潰湟の臨床一成因を中心として一，胃と腸，13，177-184，1978.

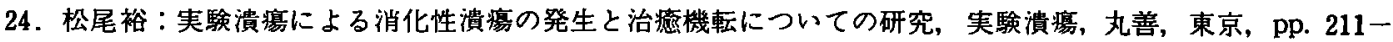
$220,1976$.

25. Brodie, D.A. and Hooke, K.F.: The effect of vasoactive agents on stress-induced gastric hemorrhage in the rat. Digestion 4, 193-204, 1971.

26. Hübner, G., Klein, H.J. and Eder, M.: The gastric glands of the rat after stimuration with pentagastrin, histalog and in acute stress. Acta Hepato-Gastroenterol 19, 388-394, 1972.

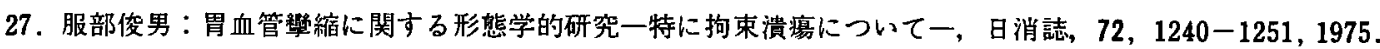

28. 松岡 茂, 中川俊二, 松岡 研：ストレス潰瘍の発生機序をめぐって,ストレス演演, 新興医学, 東京, pp. $9-19,1978$.

29. 竹内 正：腎内血管晸縮の形態学と腎内血行動態，日病会誌，63，63-89, 1974 .

30. 毛利喜久男：ストレス溃嫁の成因一脈管学および血液学の立場より一, 実験漬堨, 丸善, 東京, pp. 241一 248,1976 . 


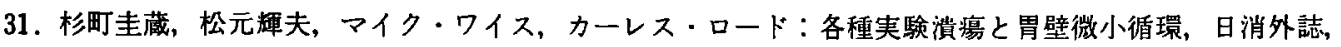
$11,75-80,1978$.

3. 宍戸輝男：拘束性胃出血の発生機序に関する実験的研究一胃粘膜微小循環系の変化を中心にして一, 日消 誌, 67, 190-200, 1970 .

33. Guth, P.H. and Hall, P.: Microcirculatory and mast cell changes in restraint-induced gastric ulcer. Gastroenterology 50, 562-570, 1966.

34. Palmer, E.P. and Sherman, J.L.: Hypoxia of abnormal physiologic origin as the final common pathway in gastroduodenal ulcer genesis. Arch. Int. Med. 101, 1106-1117, 1958.

35. 小林航三：胃の動静脈吻合に関する実驗的研究, 日消誌, 70,8-21, 1973.

36. 浅見恵司：胃壁動静脈吻合についての考察，血液と脈管，1，121-128，1970.

37. Leonard, A.S., Long, D., French, L.A., Péter, E.T., Wangensteen, O.H.: Pendular pattern in gastric secretion and blood flow following hypothalamic stimulation-origin of stress ulcer? Surgery 56,109 $-120,1964$.

38. Brodie, D.A., and Hanson, H.M.: A study of the factors involved in the production of gastric ulcers by the restraint technique. Gastroenterology 38, 353-360, 1960.

39. 鳥海達彌：Stress 潰煌の実験的研究，慈恵誌，71，1876-1881，1956.

40. Shay, H., Komarov, S.A., Gruenstein, M.: Effects of vagotomy in the rat. Arch. Surg. 59, 210-226, 1949 .

41. Matumoto, T., Wolferth, C.C., Hayes, M.F.: Surgical management of diffuse hemorrhage from gastric mucosa. Am. J. Surg. 121, 129-133, 1971.

42. 川村 功：胃局所粘膜血流に関する研究一胃体部と幽門前庭部の比較一, 日消誌, 72, 846-856, 1975.

43. Sullivan, R.C., Rutherford, R.B., Waddell, W.R.: Surgical management of hemorrhagic gastritis by vagotomy and pyloroplasty. Ann. Surg. 159, 554-562, 1964.

44. 水島和雄, 岡村毅与志, 原田一道, 林 英樹, 亚木正義：実験的急性胃病変, 胃と腸, 13，223-232, 1978 .

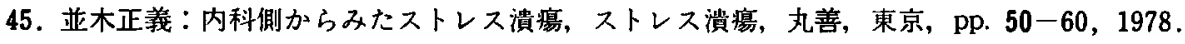

\section{附 図 説 明}

困 1 . 正常ラット腺胃体部血管鋳型断面像. $\mathrm{S}$ ：獎膜血管網。 $\mathrm{M}$ ：粘膜下血管網。 C : 粘膜細動脈。 $\mathrm{V}:$ 集合 細静脈。 $\times 65$.

図 2. 正常ラット腺胃体部粘膜表層毛細血管網の血管鋳型像．上行してきた粘膜細動脈は粘膜表層で類円形の 毛細血管網を形成し，次いで集合細静脈へ流入している，×80.

図 3.ストレス負荷30分後の血管鋳型像，毛細血管の著明な蛇行と狭小化および先細り状の血行の途絶が観察 される. $\times 80$.

图4.図3の拡大像. $\times 320$.

図 5 ．ストレス負荷 1 時間後の血管鋳型像. 毛細血管の高度の狭小化と途絶および毛細血管網の陥凹と部分的 脱落が観察される，×160.

図 6、ストレス負荷 2 時間後の血管鋳型像，毛細血管網の広範囲の脱落を見る. $\times 120$.

図 7 ．ストレス負荷 2 時間後の血管鋳型像. 類球状の樹脂の流出を伴なう毛細血管の途絶とそれに伴なう限局 した毛細血管網の脱落が観察される. × 160.

図8.ストレス負荷 3 時間後の血管鋳型像. 毛細血管網の広範囲に脱落した部に上行している細動脈は途絶し て棍棒状に拡張している。また大小不同の樹脂の流出像が多数観察される。×80.

困 9 、ストレス負荷 6 時間後の血管鋳型像. 毛細血管網の広範囲に脱落した部の細動脈と集合細静脈は表層で 
途絶して棍捧状に拡張している．また大小不同の樹脂の流出像が多数観察される， $\times 80$.

図10．ストレス負荷 6 時間後の血管鋳型の断面像，細動脈は表層で途絶し，粘膜固有層深部に達するまで棍棒 状に搪張している。この細動脈には分枝血管が全く見られない。 $\times 80 。$

図11．ストレス負荷12時間後の血管鋳型像．毛細血管網は広範围に脱落し，同部に上行している集合細静脈は 途絶して流入毛細血管を欠き，应張して表面に突出して観察される。 $\times 80$.

図12.ストレス負荷18時間後の血管鋳型像，毛細血管網の脱落は広い範囲におよんでいる，×80.

図13，ストレス負荷24時間後の胃固定標本．線状のビランが多数観察される．×2．

図14. 図13の組織光顕像。粘膜の損傷と同部の細胞の破壊と粘液の流出が見られる．×8．

図15. 図14の拡大像。粘膜下層の動脈壁の平滑筋細胞の繁縮像が見られる。 $\times 40$.

困16. ストレス負荷24時間後の血管鎛型像。広範囲の毛細血管網の脱落と同部に上行している細動脈の粘膜固 有層中部での途絶々粘膜固有層深部に達する拡張した像が観察される。 $\times 80$.

図17．幹迷切後負荷 30 分後の血管鋳型像. 毛細血管の高度の蛇行と狭小化，毛細血管網の軽度陥凹が見られる。 $\times 160$.

図18. 幹迷切後負荷 1 時間後の血管鋳型像。毛細血管には蛇行と狭小化およびときに先細り状の途絶した像が 見られ，集合細静脈とその流入毛細血管には著明に拡張した像が見られる。 $\times 80$.

図19. 幹迷切後負荷 2 時間後の血管鋳型像. 毛細血管の著明な狭小化とわずかの先細り状の血行の途絶が見ら れる. $\times 80$.

図20．幹迷切後負荷 2 時間後の血管鋳型像。毛細血管網の表層での部分的脱落が観察される， $\times 80$.

図21．幹迷切後負荷 3 時間後の血管釷型像，毛細血管の全体にほほ均一な狭小化と毛細血管網の部分的脱落が 見られる。 $\times 80$.

図22. 幹迷切後負荷 6 時間後の血管鋳型像。毛細血管の著明な狭小化と毛細血管網のやや広い範囲での陥凹が 見られる。 $\times 80$.

図23. 幹迷切後負荷12時間後の血管鋳型像. 毛細血管網の部分的脱落と集合細静脈とその流入毛細血管の著明 な应張が見られる。 $\times 80$.

図24. 幹迷切後負荷18時間後の血管鋳型像。毛細血管の先細り状の途絶と毛細血管網の部分的脱落がやや多数 観察される。 $\times 80$.

図25. 幹迷切後負荷24時間後の組織光顕像. 粘膜の損傷は認められない. $\times 8$.

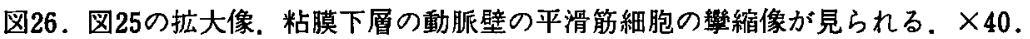

図27. 幹迷切後負荷24時間後の血管鋳型像. 毛細血管の軽度蛇行と㹟小化およU゙途絶，その血管破綻部に一致 して極めてわずかの類球状の樹脂の流出，毛細血管網の軽度陥凹と部分的脱落が見られる。 $\times 80$.

图28，ストレス 2 時間負荷後24時間放置群の血管鋳型像，毛細血管と細動脈の途絶と毛細血管網の小範囲の部 分的脱落が見られ、この途絶している毛細血管と細動脈の先端にはしばしばY状に発芽生長した血管像が 見られる。 $\times 80$.

図29. 図28の拡大像。発芽した血管には互に接近している像も見られる．×320.

図30．ストレス24時間負荷後48時間放置群の血管鋳型像。ストレス演演の形成された粘膜部の毛細血管網は脱

落し，同部の途絶した細動脈と集合細静脈には不規則な発芽像が見られる，×120．

図31. 図30の拡大像。発芽血管は不規則で不正形のコプの様に見える．×800.

図32、ストレス24時間負荷後120時間放置群の血管鋳型像。再生血管部は網状構造を有しな健常部と比較してな お宿凹している。再生細動脈と再生集合細静脈は不規則に上行しているが再生細動脈相互間の分枝吻合血 管は見られない，表層では不規則に連絡しているが網状構造は未だ不完全である．×80．

区33. 四32の拡大像。再生細動脈と再生集合細静脈との連絡は不十分である。 $\times 320$. 


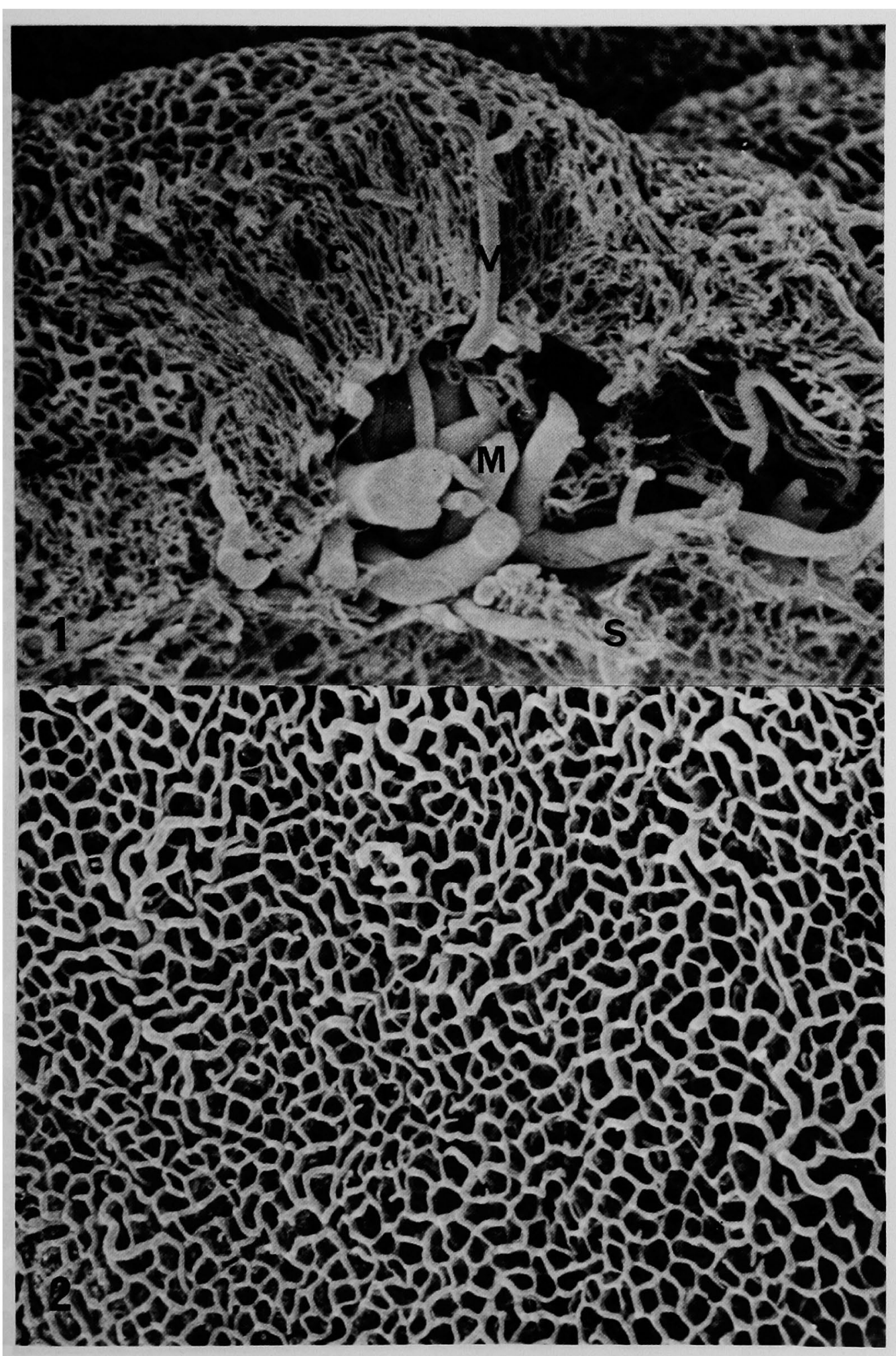




\section{近沢信僮論文附図}

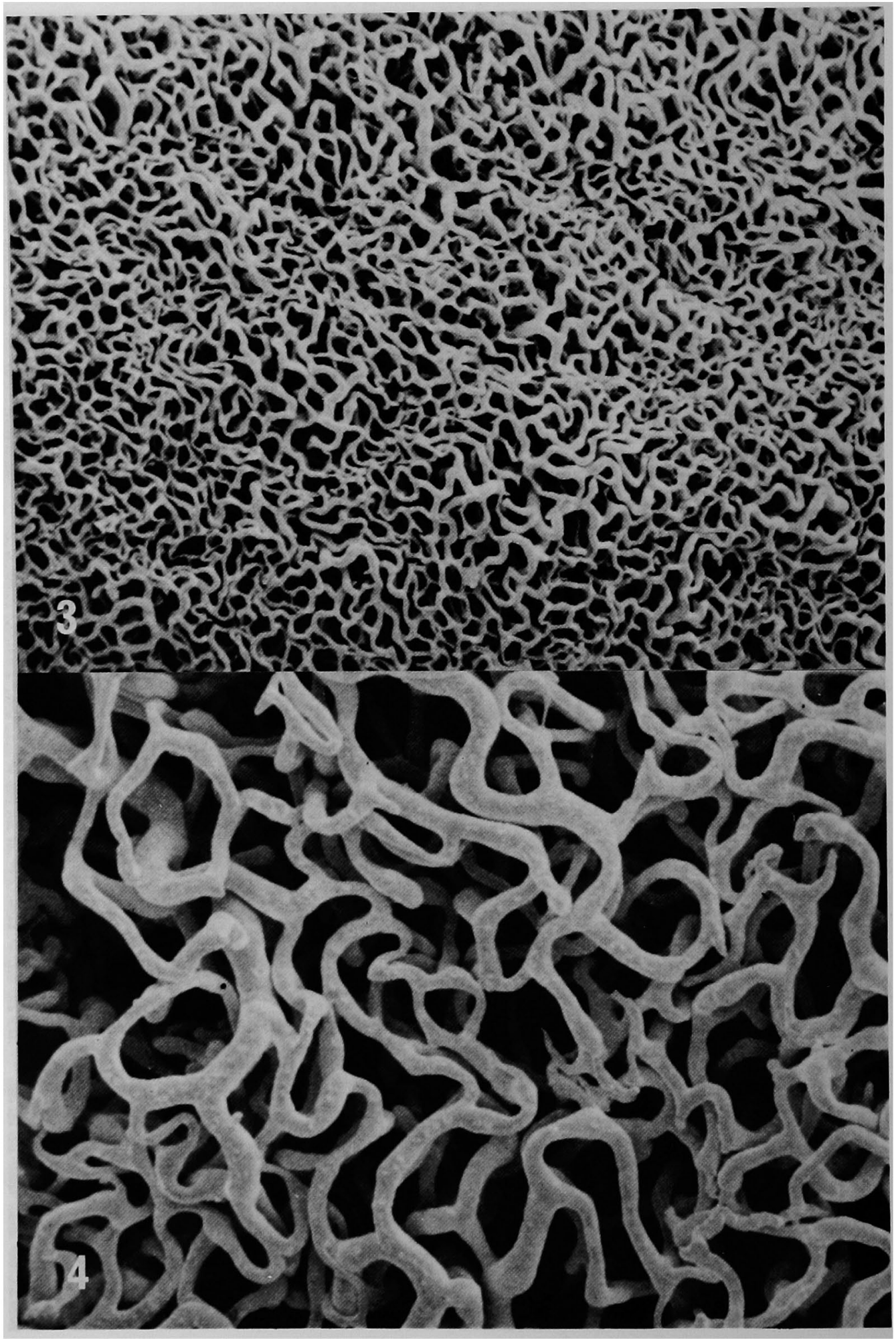




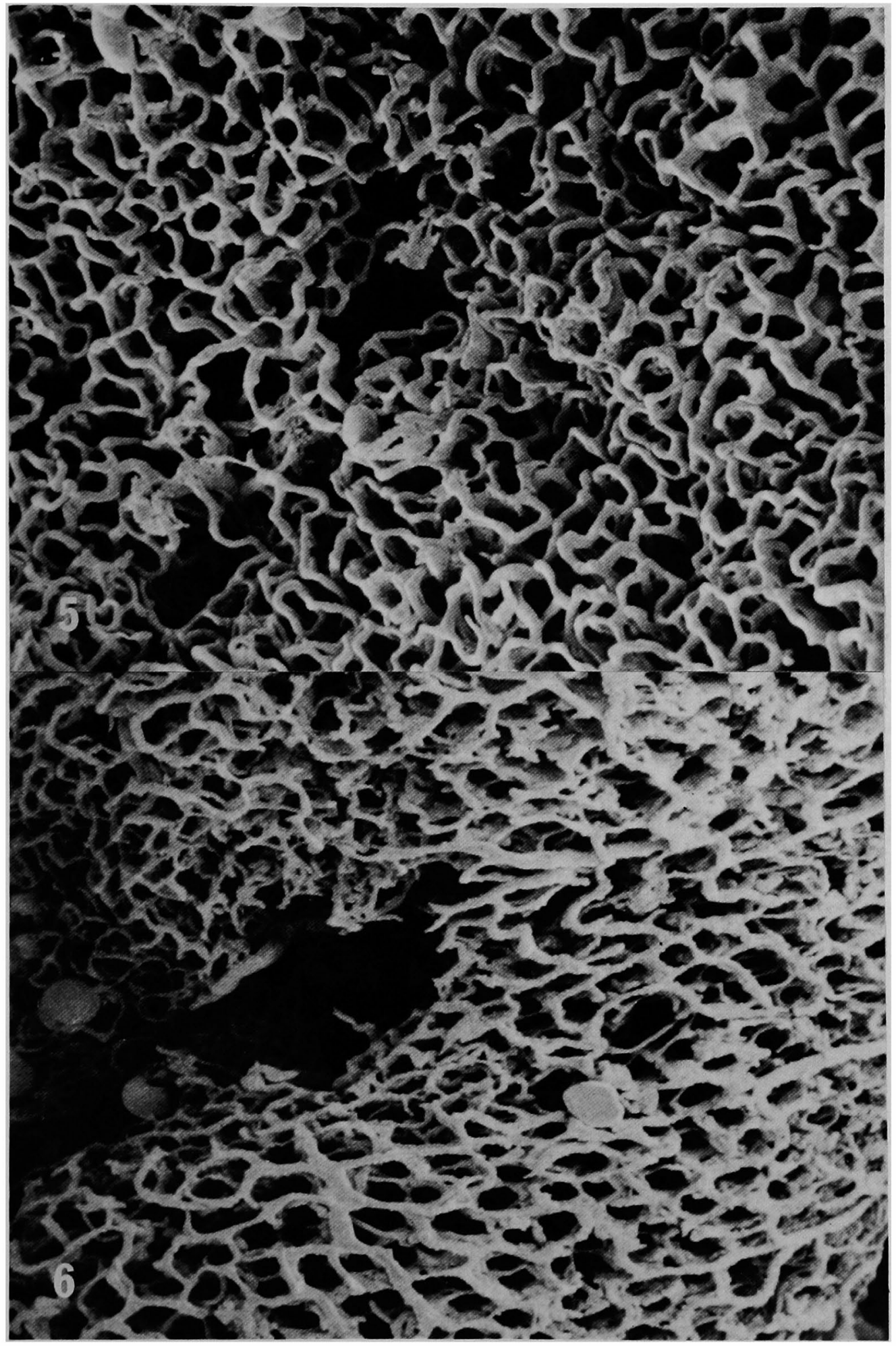


近沢信儀論交附図

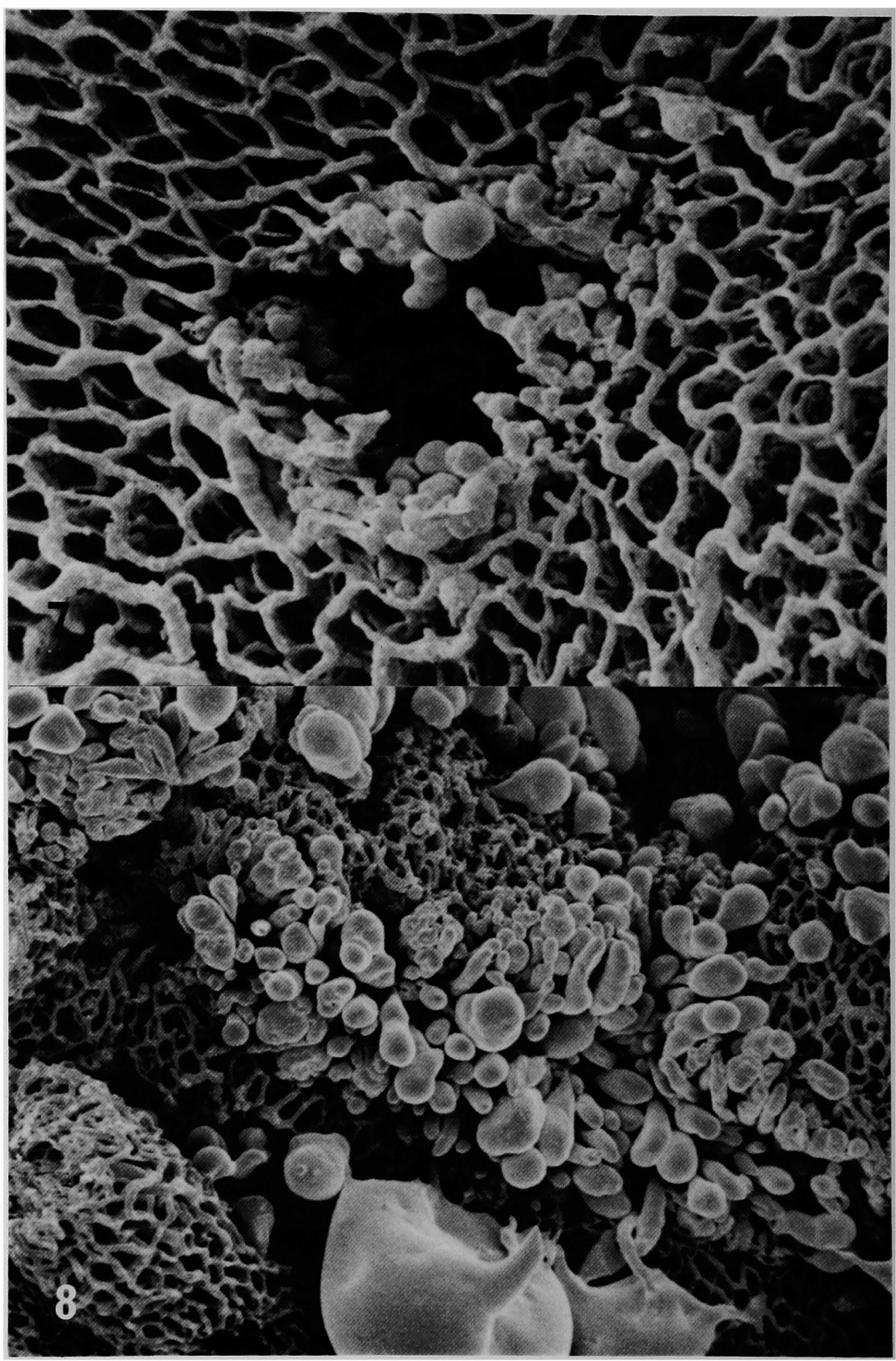


近沢信儀論文附図




近沢信儀論文附図

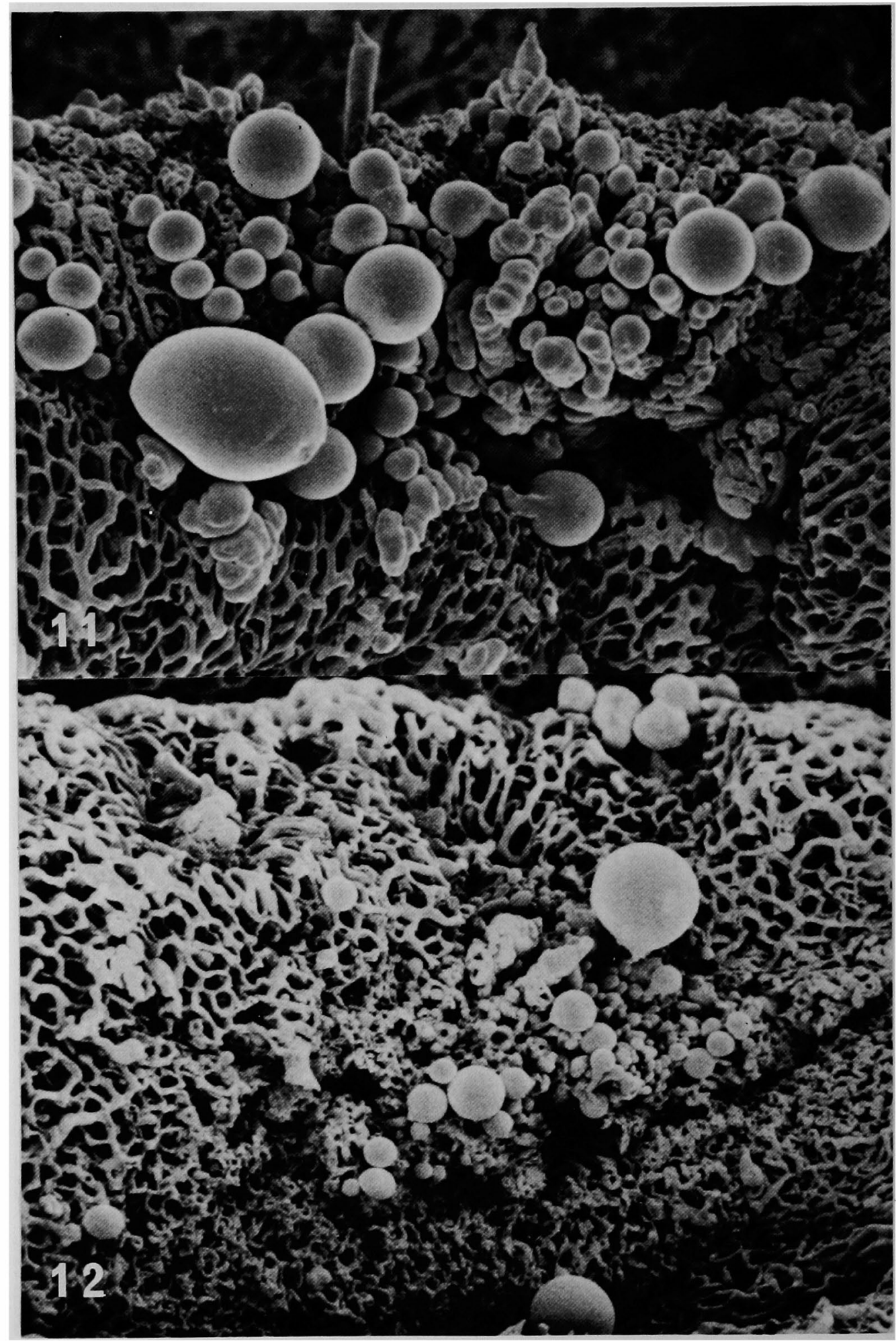




\section{近沢信儀論交附図}

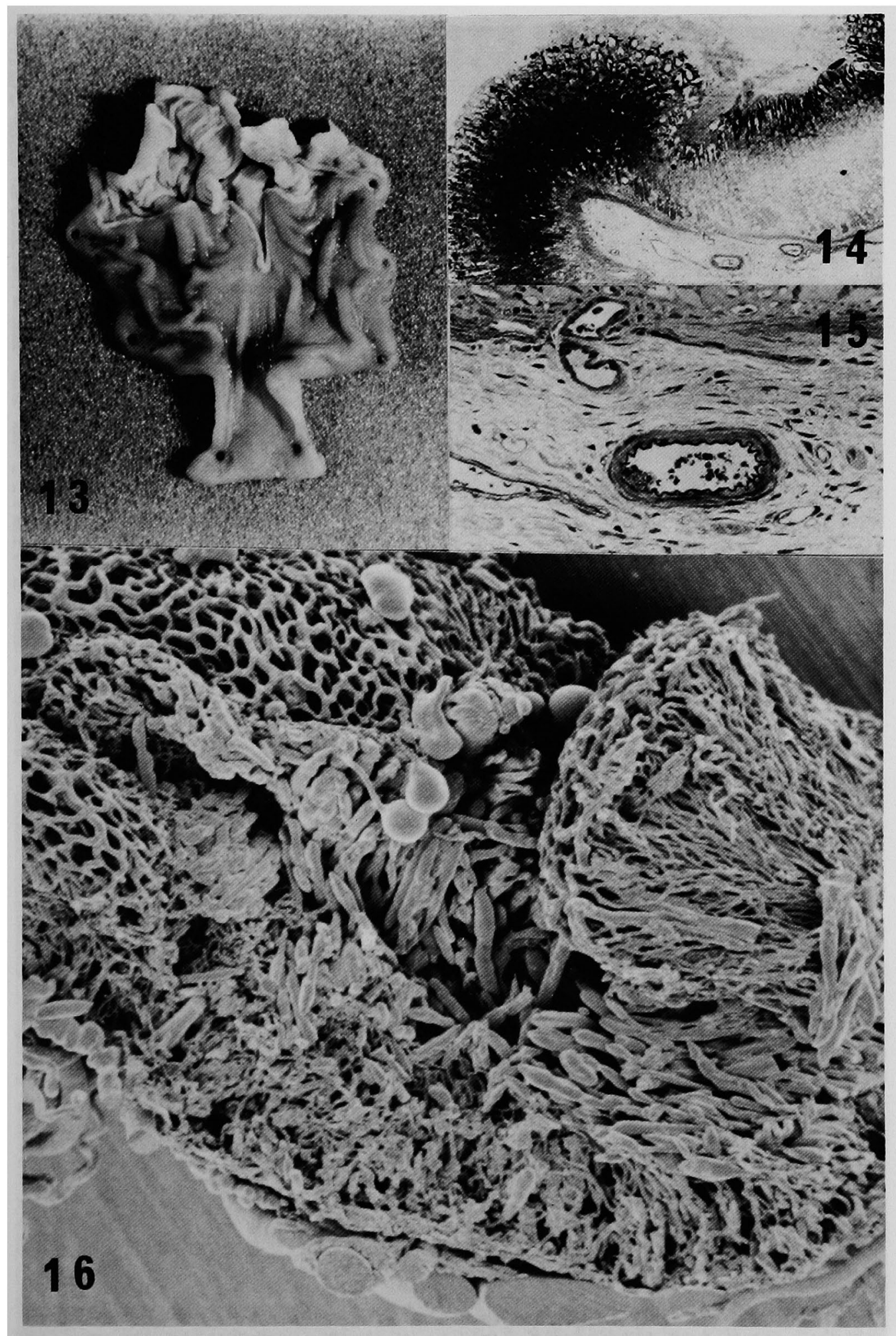




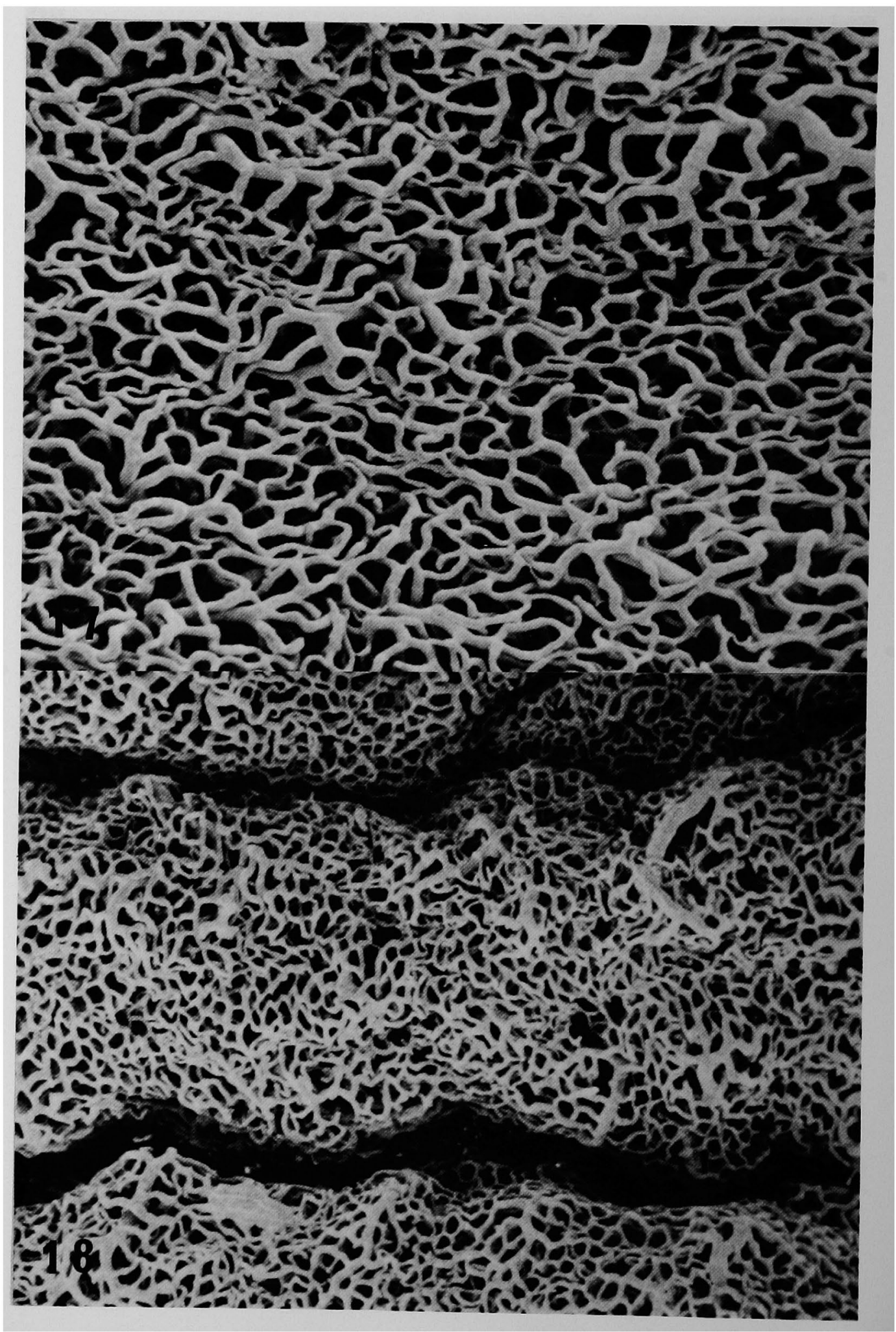


近沢信儀論交附図

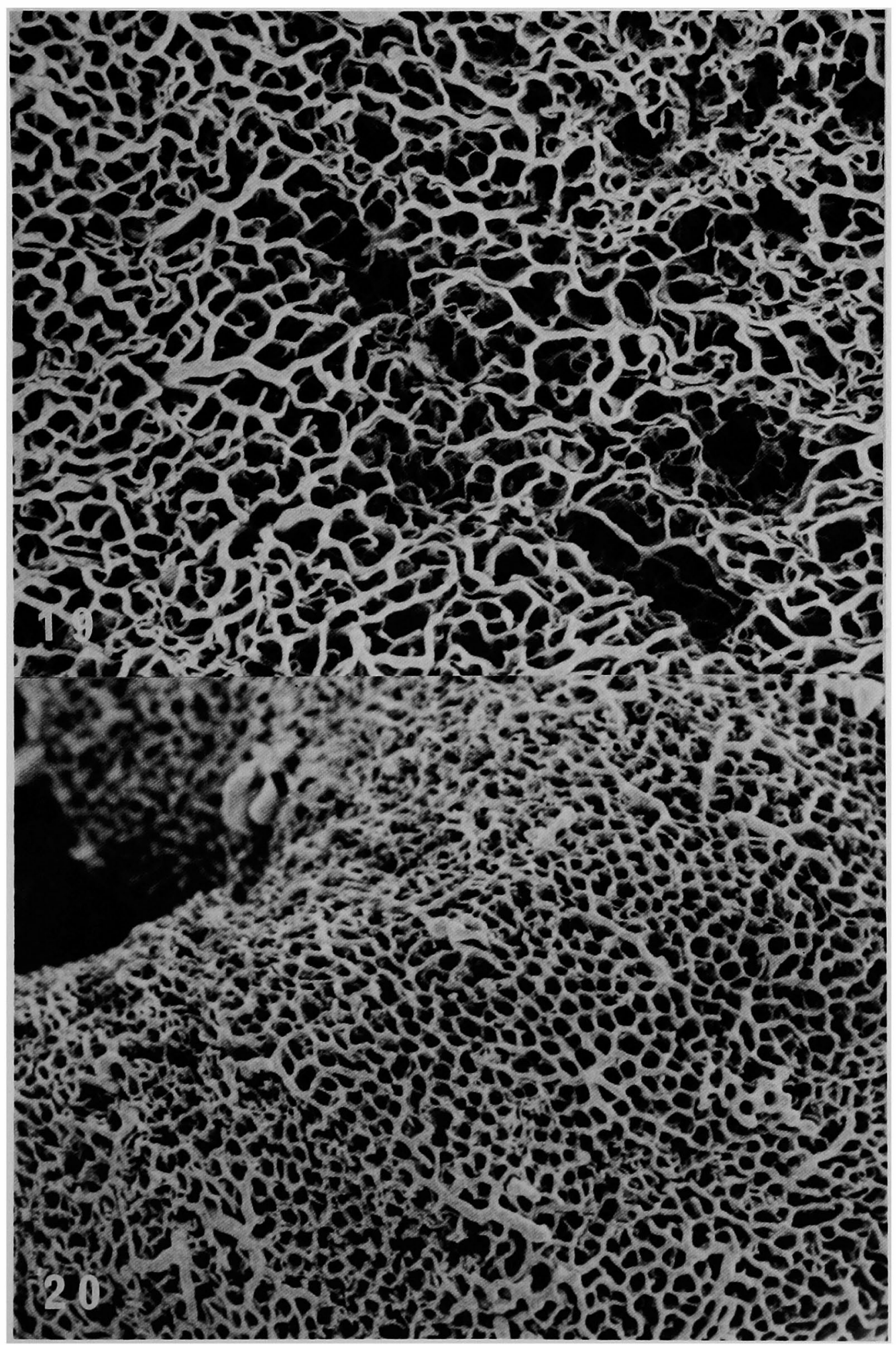


近沢信儀論文附図

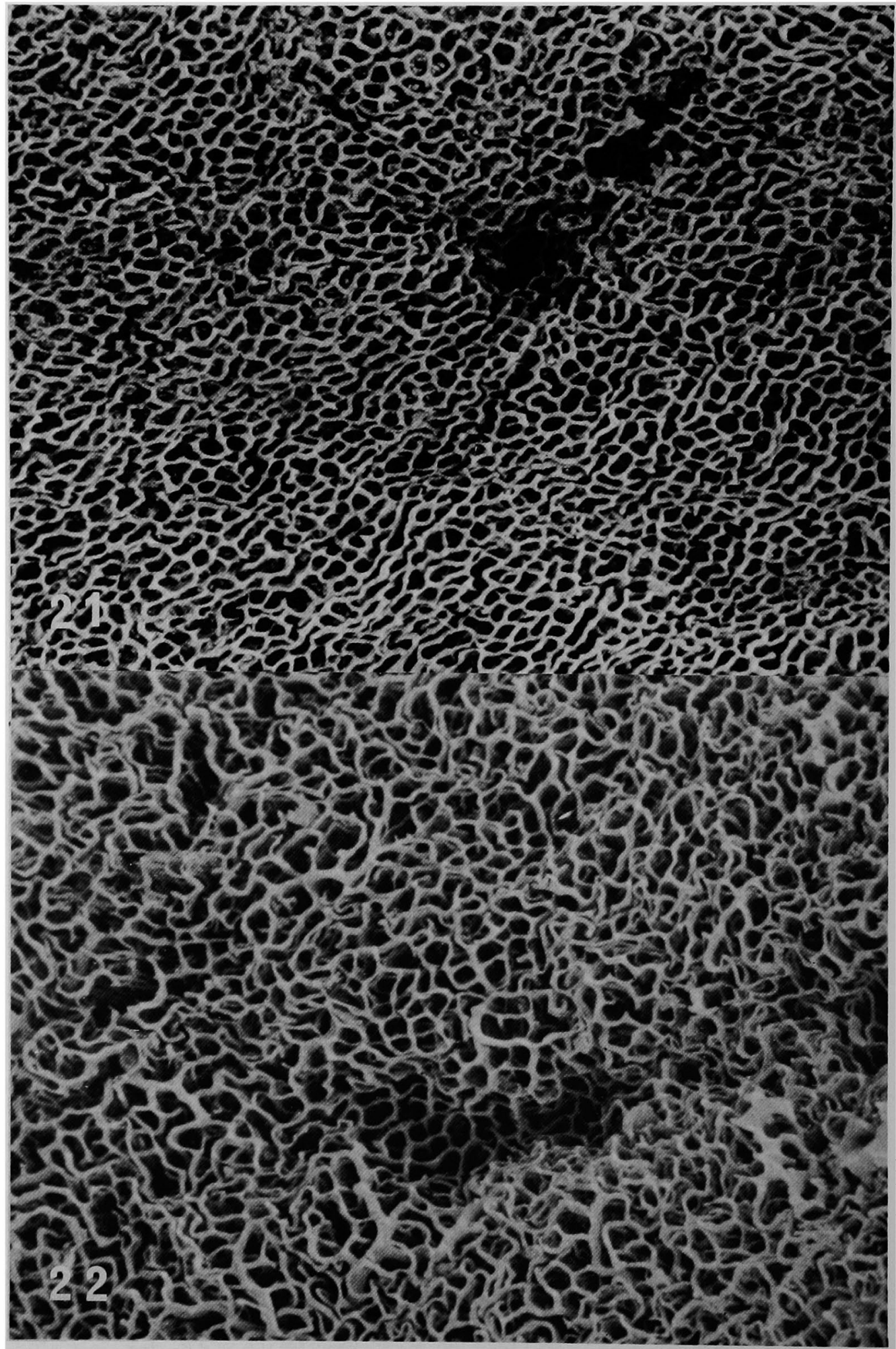




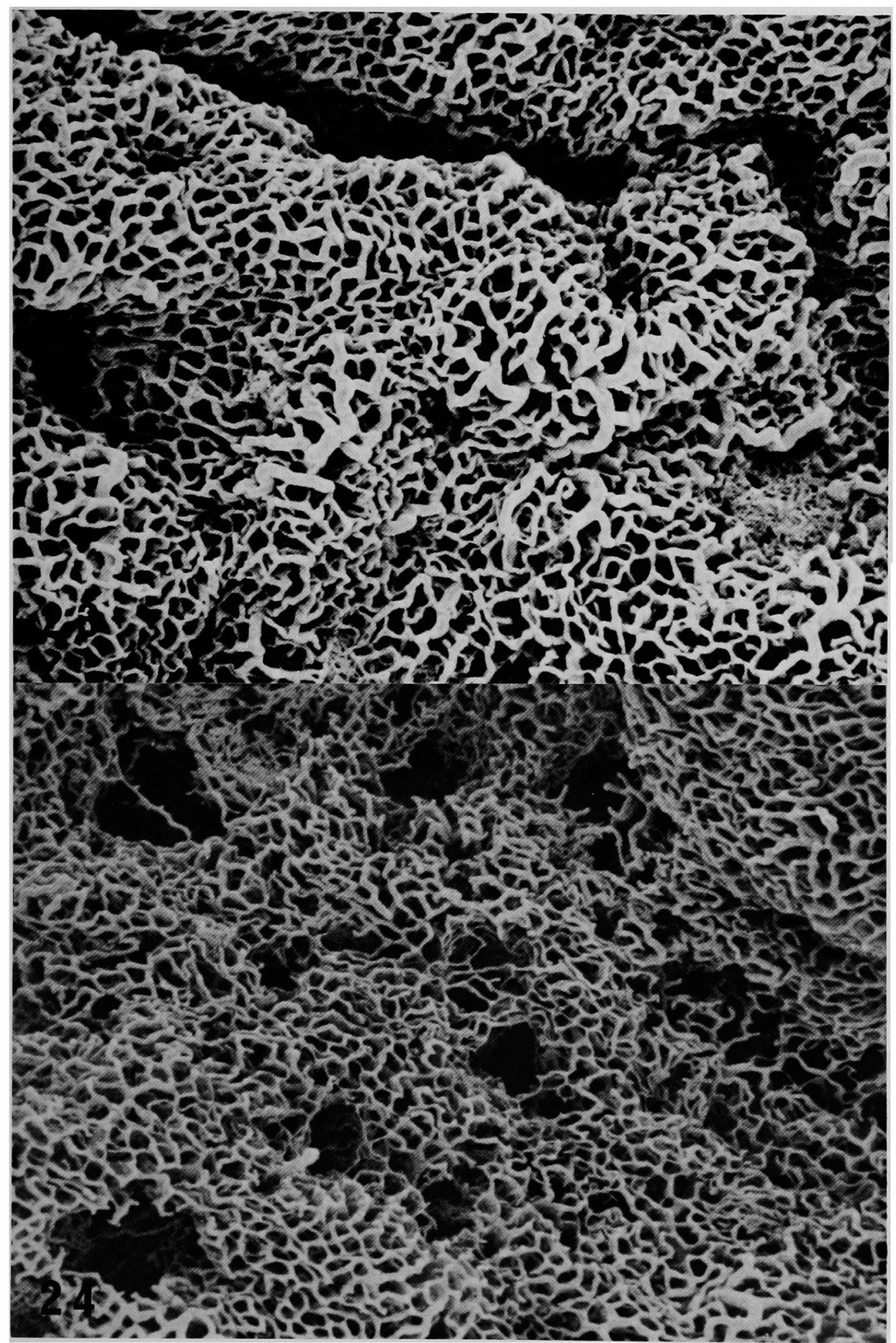




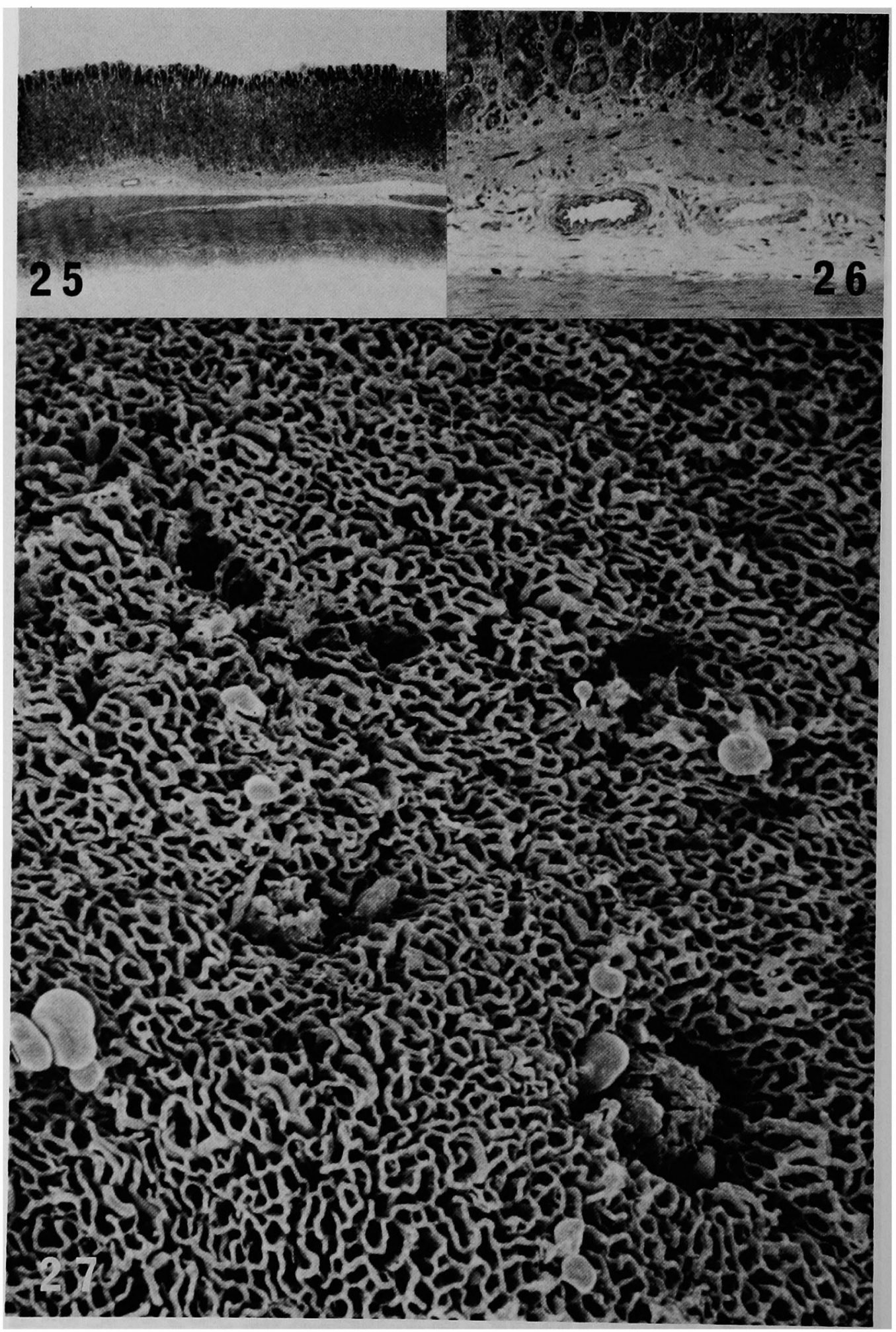




\section{近沢信儀論交附図}

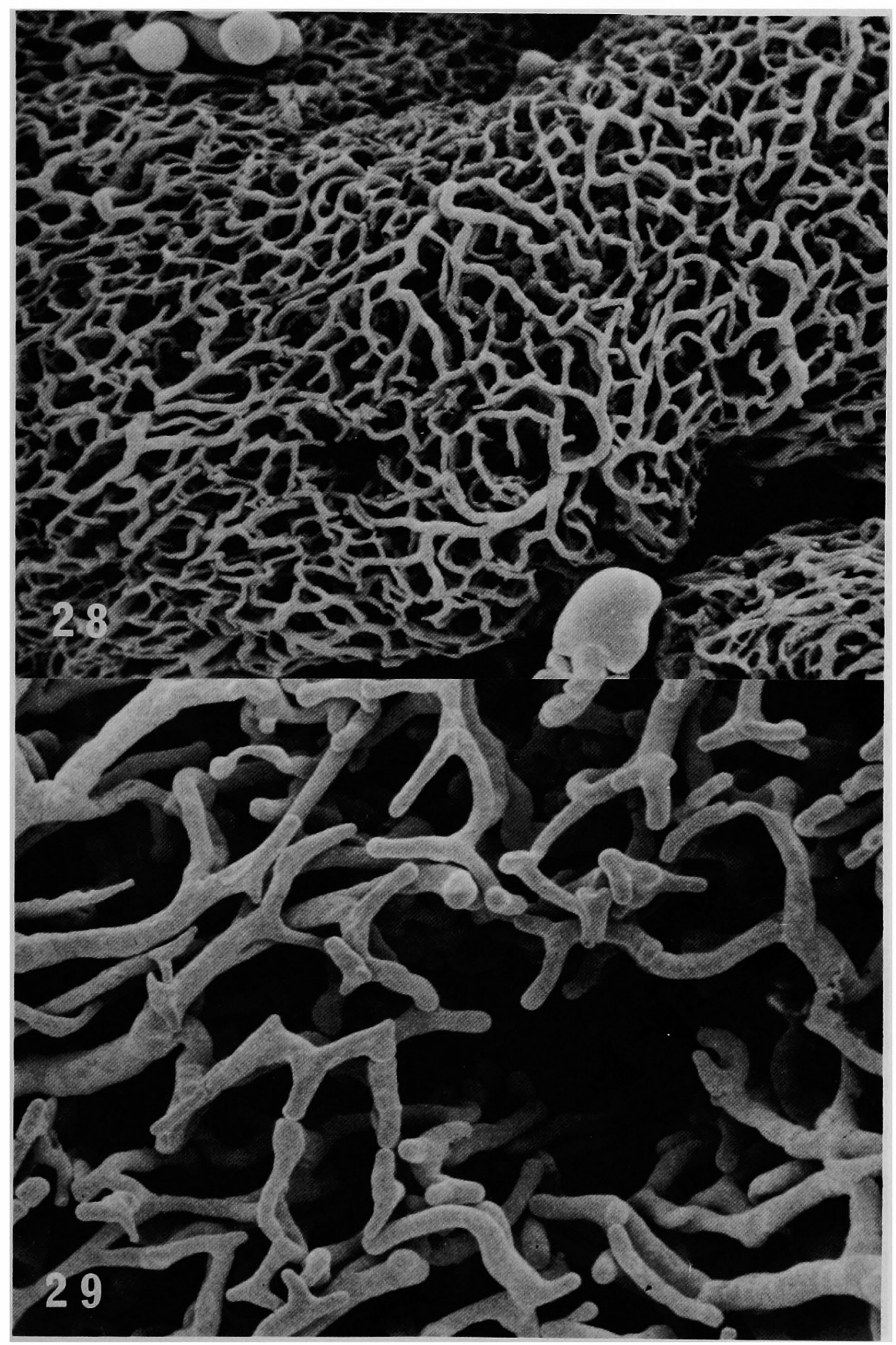




\section{近沢信儀論文附図}

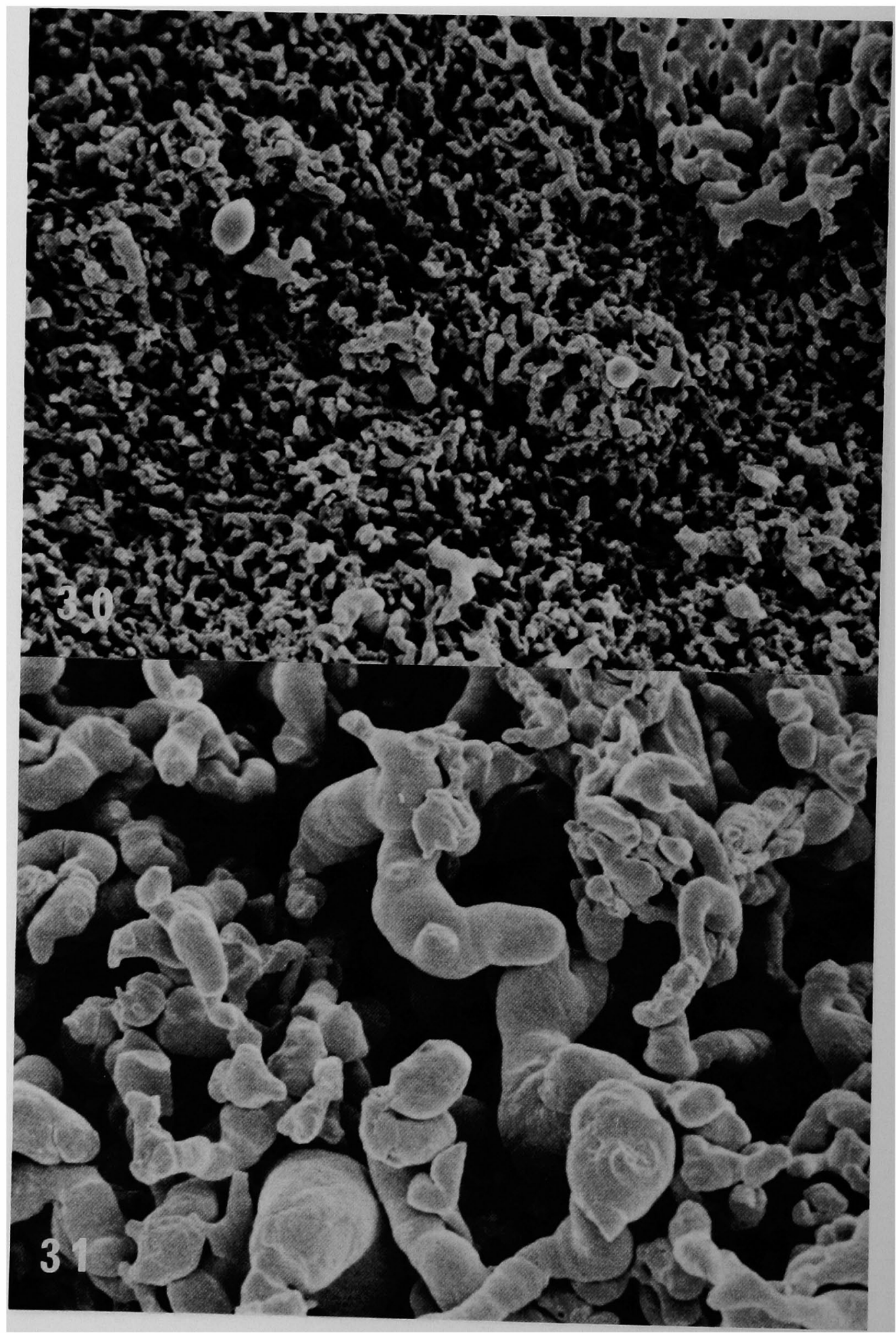


近沢信儀論文附図

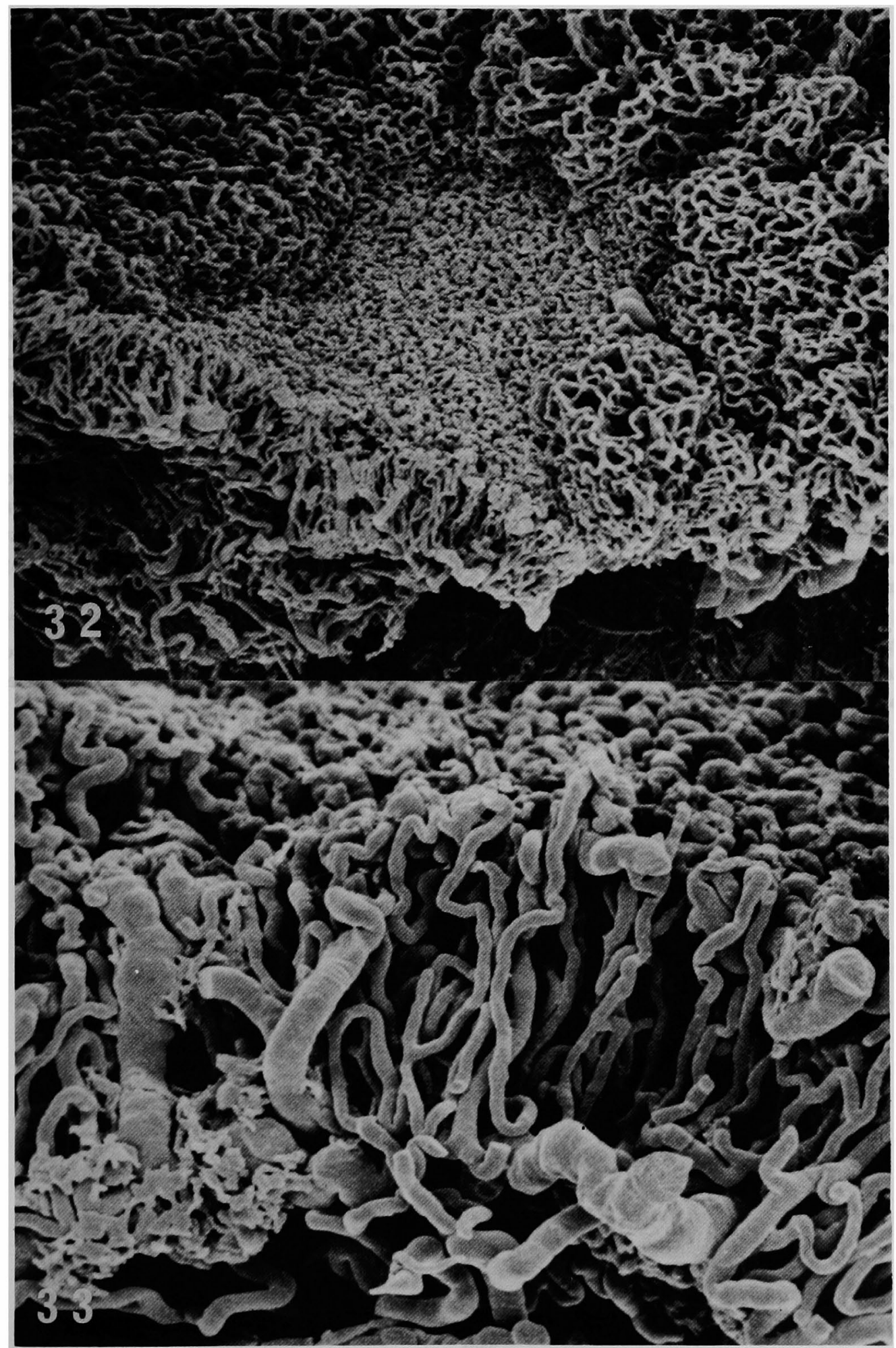




\section{Microvascular changes of gastric mucosa in the development of stress ulcer in rats \\ A scanning electron microscopic study of vascular casts Nobuyoshi CHIKaSAWA \\ The First Department of Surgery, Okayama University Medical School, \\ Okayama, Japan \\ (Director : Professor K. Orita)}

Under a scanning electron microscope, the microcirculation in the stomachs of rats under stress was observed by a corrosion casting technique. Stress ulcers were induced by a cold immersion and restraint method. After a short time of stress, the vascular pattern showed serpentining and narrowing of the capillaries and a local depression of the capillary network. After a moderately long time, defects in the vascular network began to appear and outflowings of Mercox from the venule became prominant. Casts of interrupted collecting venules were frequently seen. With further increase in the time of stress, the interruptions in the cast of the capillaries and collecting venules which were dilated, increased. These vessel changes descended deeper and deeper into the mucosa vessels but were limited to the laminapropria and did not extend to the muscularis mucosae. After stress following truncal vagotomy, the vasculature showed serpenting and narrowing of the capillaries. But there were few defects in the capillaries and capillary network.

In the case released from a short time of stress, $Y$-shaped duplicated vessels were often observed on the defective capillaries. In the case released from prolonged stress, newborn buds were seen on the defective capillaries and collecting vessels. Duplicated capillaries and collecting vessels ran toward the surface of the mucosa. 